\title{
Pharmacogenetics of Methadone Response
}

Francina Fonseca, 1,2,3

Marta Torrens, $1 \bowtie, 2,3$

Phone +34932483175

Emailmtorrens@parcdesalutmar.cat

1 Institut de Neuropsiquiatria i Addiccions, Hospital del Mar, Passeig Marítim 25-29, 08003 Barcelona, Spain

2 IMIM (Institut Hospital del Mar d'Investigacions

Mèdiques), Barcelona, Spain

3 Department of Psychiatry, Universitat Autònoma de Barcelona, Barcelona, Spain

\section{Abstract}

The efficacy of methadone maintenance treatment (MMT) in opioid use disorder is well established but responses vary. The influence of methadone pharmacodynamics and pharmacokinetics on dose requirements and program outcomes remains controversial despite the increasing number of studies evaluating genetic influences on response to methadone treatment. Furthermore, patients require different doses (usually between 60 and $100 \mathrm{mg} /$ day), and there are no clear data on a plasma concentration associated with treatment success. We review the evidence regarding the influence of genetics on pharmacokinetic and pharmacodynamic factors in terms of MMT outcome. We also analyse the influence of genetics on the occurrence of severe adverse events such as respiratory depression and ventricular arrhythmia in methadone treatment. The outcomes of MMT may be influenced by a combination of environmental, drug-induced, and genetic factors. The influence of pharmacokinetic genetic variability can be clinically managed by modifying the posology. A better understanding of pharmacodynamic factors could help in selecting the best opioid for 
substitution treatment, but patient phenotype must still be considered when establishing a maintenance treatment. Pharmacogenetic studies represent a promising field that aims to individualize treatments according to genetic backgrounds, adapting medication and doses according to possible outcomes and the risk of adverse events.

\section{Electronic supplementary material}

The online version of this article (https://doi.org/10.1007/s40291-017-0311-y) contains supplementary material, which is available to authorized users.

\section{Key Points}

The results of methadone maintenance treatment (MMT) are influenced, both positively and negatively, by genetic, environmental, and drug-induced factors.

Treatment outcomes could be directly related to pharmacodynamic and/or pharmacokinetic factors.

The influence of genetic variability in the coding genes involved in the pharmacokinetics of methadone metabolism and transport can be clinically managed, usually by increasing or decreasing methadone doses or splitting the daily dose.

\section{Opioid Addiction: A Relapsing Complex Disease}

Opioid use disorder is a chronic, relapsing condition that involves elevated costs for individuals, families, and society. Opiates, opioids, and prescription opioids continue to be one of the most problematic drug groups worldwide. The 2016 World Drug Report by the United Nations Office on Drug and Crime estimated that $0.4 \%$ of the global population aged $15-64$ years, or the equivalent of some 17 million people, had consumed opiates and opioids in 2014 [1]. Opioid addiction is a complex disease with interacting issues, including environmental factors (cues, conditioning, stress, etc.), drug-induced neurobiological changes (the reward circuits in the basal ganglia and extended amygdala, involving dopamine, corticotropin-releasing factor, and dynorphin; and impairments in executive functions mediated by glutamate in the prefrontal cortex, insula, and basal ganglia), and individual characteristics (genetics, medical and psychiatric comorbidity, personality, and stress responsiveness), that result in the 
compulsive behaviour of drug seeking $[2,3,4]$.

The two main treatment strategies in opioid dependence are abstinence oriented and medication assisted [5]. The goal of the former is to remove the abused opioid during a detoxification process and undergo a complete lifestyle change, whereas the objective of the latter is to stabilize brain neurochemistry by replacing a short-acting opioid with a long-term acting opioid that has relatively steady-state pharmacokinetics. Opioid agonist maintenance treatment is designed to minimize the effect of the euphoria associated with the administration of illicit opioids and eliminate opioid withdrawal syndrome [6].

Methadone maintenance treatment (MMT) is the most widely used therapy for heroin and prescription opioid use disorder and has been shown to be effective in opioid-dependent subjects who stay in treatment $[7,8,9]$. Criteria for successful MMT may vary between countries and/or centres but usually include improvement of retention in treatment $[10,11]$; decreased illicit opioid use, risk behaviour related to HIV/sexually transmitted diseases [12], criminal behaviour related to drug use [13], and overdose mortality risk [14]; and augmented health-related quality of life [15]. No specific dose to achieve these "response criteria" has been established, and patients can require different doses [16]; this variability has been related in part to the pharmacologic properties of the molecule.

\subsection{Methadone Pharmacokinetics}

Methadone is a chiral molecule. This means the chemical structure includes an asymmetrical carbon atom that leads to two enantiomeric forms with the same chemical structure but different spatial dispositions so that one is the mirror image of the other. The methadone usually employed in the treatment of addiction and pain contains both enantiomers in the same proportion (racemate): $(R)$ - or levo- or 1-methadone and $(S)$ - or dextro- or d-methadone. The pharmacodynamics of each enantiomer differs: $(R)$-methadone has a higher affinity for opioid receptors than $(S)$-methadone, and greater analgesic potency has also been reported [16]. The $(R)$-methadone enantiomer produces the main therapeutic effects of methadone, whereas $(S)$-methadone is usually associated with adverse events $[16,17,18]$. The pharmacokinetic profiles of the enantiomers also differ: the $(R)-/(S)$-methadone plasma concentration ratio varies during the $24 \mathrm{~h}$ after administration $[19,20]$. Plasma concentrations also differ between subjects [18], which may explain range of responses to 
treatment.

The marked inter-individual differences in methadone pharmacokinetics is considered the main explanation for the range of doses required to achieve treatment success [16]. These differences have been previously described in relation to bioavailability, plasma protein binding, volume of distribution, total body clearance, and elimination half-life. Oral bioavailability has been reported to range from 36 to $100 \%$ [16], with such a broad range partly explained by the action of intestinal cytochrome P450 (CYP)-3A4 [21]. A number of studies have also reported inter-individual variability in the free fraction of plasma methadone [22], in addition to a distribution volume with a mean of $41 / \mathrm{kg}$ and a range of $2-131 / \mathrm{kg}$ [23]. Although distribution volume has no direct effect on steady-state plasma concentrations, changes in the unbound fraction of methadone could modify the volume of distribution [20].

Results from studies focused on finding optimal methadone plasma concentrations for effective MMT have been contradictory [24, 25, 26]. Some were unable to find such a threshold concentration [26, 27, 28], whereas others described a relationship between methadone plasma concentration and outcomes such as presence of withdrawal symptoms [24, 29] and illegal drug use, detected with random urine analysis [25]. The proposed values usually range from 50 to $600 \mu \mathrm{g} / 1$ of $(R, S)$-methadone [30]. The measurement of methadone plasma concentrations has generally been recommended to confirm inadequate rather than optimum doses [31]. As the opioid effect of $(R, S)$-methadone is mainly due to the $(R)$-enantiomer, and some side effects (such as QTc prolongation) have been associated with $(S)$-methadone, differences in the $(R) /(S)$-methadone ratio could also explain the variability in treatment responses and tolerance. Furthermore, given the wide inter-individual variability of the $(R) /(S)$ methadone ratio, other studies have tried to correlate the concentration of $(R)$ methadone with therapeutic outcome [30, 32, 33].

Although the efficacy of MMT has been demonstrated, a significant number of patients still respond poorly [34]. An adequate dosage of methadone-usually ranging from 60 to $100 \mathrm{mg} /$ day — is the main factor associated with successful MMT $[10,35]$ and is usually correlated with higher retention in treatment. The role of variables such as sex, ethnicity, education level, employment status, years of consumption, and previous treatments in response to MMT has not been confirmed $[36,37]$. 
Nevertheless, the relationship between a patient's genetic background and their response to MMT has become a topic of interest. Most reports have focused on genetic polymorphisms in genes coding for methadone-metabolizing enzymes and transporter proteins (e.g., P-glycoprotein). Differences in response to or tolerance of MMT related not only to pharmacokinetic genetic variability but also to polymorphisms associated with pharmacodynamic factors - such as the $\mu$ opioid receptor, dopamine receptors, $\beta$-arrestin, and neurotrophins - have also been evaluated $[38,39]$. In the next section, we describe the main approaches taken in pharmacogenetic studies.

\subsection{Different Approaches to Study Pharmacogenetics}

Approaches to studying the pharmacogenetic basis of response to drugs and vulnerability to drug addiction vary. Linkage studies use families to provide evidence of how close a genetic marker is to an allele causing the phenotype in question but are complicated to perform because it can be difficult to find families with more than one affected member.

Association studies may be performed with unrelated individuals and parentoffspring trios, and associations between specific genetic variants and outcomes/traits of interest are evaluated. Variants are selected based on previous hypotheses.

In genome-wide association studies (GWAS), the entire genome of different individuals is examined to establish whether any variant is associated with a trait or disease. Such an approach can be used to detect new loci in the genome and formulate hypotheses. More than 100,000 markers across the genome are generally employed.

Epigenetic studies analyse genetic information not encoded in the DNA sequence. DNA methylation and covalent histone modifications are the primary sources of epigenetic inheritances. Changes in methylation in genomic DNA are a mechanism of control of DNA expression. MicroRNA (miRNA) is another mechanism by which gene expression is regulated post-transcriptionally; miRNA consists of short-length (18-25 nucleotides) non-coding RNA. Epigenetics and miRNAs control each other, regulating the normal expression of genes.

It is important to be aware of some limitations that could affect the validity of 
pharmacogenetic analysis results. Subjects should be correctly selected and a "good response" phenotype clearly defined. Samples from different ethnic or racial origins (population stratification) can be a source of inaccurate results because of varying therapeutic responses and allele frequencies. Another reason for errors in genetic studies is the multiple comparison issue. Studies that analyse multiple genes and/or single nucleotide polymorphisms (SNPs) must include a method to control for multiple comparison. Without this, a risk of false-positive (or type I error) is high. In GWAS studies, where more than 500,000 SNPs could be tested simultaneously, this is paramount, and $p$ values around $5 \times 10^{-8}$ are generally employed. Finally, a replication study increases the validity of positive results; lack of validation in many pharmacogenetic studies forces cautious interpretation [40].

We review the current evidence on genetic influences on pharmacodynamic and pharmacokinetic factors involved in MMT outcomes, methadone doses required, and methadone-related adverse events.

\section{Pharmacodynamic Genetic Variability}

Pharmacodynamics is the study of the biochemical and physiological effects of drugs and their mechanism of action, including correlations between their chemical structure and their actions and effects. Table 1 and the table in the Electronic Supplementary Material (ESM) summarizes the pharmacodynamic targets that have been studied, including the $\mu$ opioid receptor, dopamine receptor genes, $\beta$-arrestin 2 , neurotrophins, and genes previously involved in the risk for opioid dependence disorder.

\section{Table 1}

The main studies assessing pharmacodynamic genetic variability and its influence on methadone maintenance treatment outcomes

\begin{tabular}{|c|c|c|c|}
\hline Gene & Study & $\begin{array}{l}\text { Sample } \\
\text { characteristics }\end{array}$ & Main results \\
\hline & $\begin{array}{l}\text { Barratt } \\
\text { et al. } \\
\text { [54] }\end{array}$ & $\begin{array}{l}119 \text { Caucasian MMT } \\
\text { patients }\end{array}$ & $\begin{array}{l}\text { Wild-type } O P R M 1 \text { subjects, an } \\
A B C B I \text { variant haplotype group } \\
\text { had significantly lower doses } \\
\text { than } A B C B 1 \text { wild-type }(35 \pm 5 \\
\text { vs. } 180 \pm 65 \mathrm{mg} / \text { day; } p<0.01) \\
\text { and } C \text { trough }(78 \pm 22 \text { vs. } \\
177 \pm 97 \mathrm{ng} / \mathrm{ml} ; p<0.05) \text {. In } \\
\text { subjects with the most common } \\
A B C B 1 \text { haplotype combination, } \\
\text { the } O P R M 1118 \mathrm{~A} / \mathrm{G} \text { genotype }\end{array}$ \\
\hline
\end{tabular}


was associated with a significantly higher $\mathrm{C}$ trough than $118 \mathrm{~A} / \mathrm{A}(250 \pm 126 \mathrm{vs}$. $108 \pm 36 \mathrm{ng} / \mathrm{ml} ; p=0.016)$

\section{Han Chinese}

MMT patients: 92 low

OPRM1, ABCB1, CYP2B6, dose ( $<55 \mathrm{mg} /$ day);

Hung et

150 medium dose al. [55]

(55-99 mg/day); 79

high dose (100-

$150 \mathrm{mg} /$ day)

$A N K K 1$, and $D R D 2$ genetic variants were jointly correlated with optimal methadone dose (adjusted $r^{2}=53 \%$ )

No association between genotype and MMT outcome:

Crettol

238 Caucasian MMT et al. patients: $165 \mathrm{R}$ (40AA carriers: AA 118 (72\%) R vs. 59 (81\%) NR

[56] $120 \mathrm{mg} /$ day), $73 \mathrm{NR}$ (> $120 \mathrm{mg} /$ day)

AG carriers: 44 (27\%) R vs. 13 (18\%) NR

GG carriers: 3 (2\%) R vs. 1 (1\%) NR $(p=0.3)$

Fonseca et al. [58] OPRM1
116 Caucasian MMT patients: $83 \mathrm{R}$ $(100 \pm 68 \mathrm{mg} /$ day $) ; 33$ NR (78 $\pm 43 \mathrm{mg} /$ day)

366 Han Chinese MMT patients

Wang et $\quad(54.7 \pm 28.1 \mathrm{mg} /$ day $)$. al. [59] Methadone plasma concentrations $193.07 \pm 121.76 \mathrm{ng} / \mathrm{ml}$

Levran et al. [60] undergoing stable MMT

$(141 \pm 51 \mathrm{mg} / \mathrm{day})$ 227 Israeli patients

No association between genotype and MMT outcome: R: $75 \%$ A $25 \%$ G vs. NR: $75 \%$ A $25 \% \mathrm{G} ; p=0.96$

No association with response, methadone dose, nor plasma concentrations with any of the SNPs

Carriers of the $\mathrm{G}$ allele required lower doses of methadone $(132.4 \mathrm{mg} \pm 50.7 \mathrm{vs}$. $147.4 \pm 49.7 \mathrm{mg} ; p=0.028$ in a dominant model)

SNP associated with: mean methadone dose $(68.0 \pm 30.1 \mathrm{mg})$ and rs73568641 $\left(p=2.8 \times 10^{-8}\right)$; each minor $(C)$ allele corresponded to an
Smith et 383 African American al. [51] subjects in MMT additional $\sim 20 \mathrm{mg} \mathrm{day}^{-1}$ of oral methadone. Children being treated for surgical pain, rs73568641-C was associated with a higher required dose of morphine $(n=241$, $\left.p=3.9 \times 10^{-2}\right)$. Not replicated in Caucasian sample $(77.8 \pm 33.9 \mathrm{mg})$

Methadone patients with the 283 European Americans in MMT.

Crist et al. [61] Mean maximum dose $99.6 \pm 46.0 \mathrm{mg} / \mathrm{day}$.
A/A genotype at rs 10485058 were less likely to have opioidpositive urine drug screens than 


\begin{tabular}{|c|c|c|c|}
\hline & & $\begin{array}{l}\text { Opioid-positive urine } \\
\text { drug screens } 36.0 \%\end{array}$ & $\begin{array}{l}\text { those in the combined } \mathrm{A} / \mathrm{G} \text { and } \\
\mathrm{G} / \mathrm{G} \text { genotypes group. RR } 0.76 \text {, } \\
95 \% \text { CI } 0.73-0.80 ; p=0.0064)\end{array}$ \\
\hline OPRD1 & $\begin{array}{l}\text { Crist et } \\
\text { al. }[66]\end{array}$ & $\begin{array}{l}77 \text { African Americans } \\
\text { (MTD methadone } \\
\text { mean } \\
\text { dose }=99.7 \pm 46.4) \\
\text { and } 566 \text { European } \\
\text { Americans (MTD } \\
\text { methadone mean } \\
\text { dose }=79.2 \pm 26.5) \\
\text { undergoing treatment } \\
\text { for opioid dependence } \\
\text { (MMT or } \\
\text { buprenorphine) }\end{array}$ & $\begin{array}{l}\text { Methadone patients with the } \\
\text { CC genotype were less likely to } \\
\text { have opioid-positive urine tests } \\
\text { than those in the combined CT } \\
\text { and TT genotypes group (RR } \\
0.52,95 \% \text { CI } 0.44-0.60 ; \\
p=0.001)\end{array}$ \\
\hline \multirow{6}{*}{$D R D 2$} & $\begin{array}{l}\text { Crettol } \\
\text { et al. } \\
{[56]}\end{array}$ & $\begin{array}{l}238 \text { Caucasian MMT } \\
\text { patients: } 165 \mathrm{R}(40- \\
120 \mathrm{mg} / \text { day }) ; 73 \mathrm{NR} \\
\text { (>120 mg/day) }\end{array}$ & $\begin{array}{l}\text { Carriers of } 957 \mathrm{CC} \text { genotype } \\
\text { were more frequently NR: } 12 \\
\text { vs. } 25 \%(p=0.05)\end{array}$ \\
\hline & $\begin{array}{l}\text { Doehring } \\
\text { et al. } \\
\text { [68] }\end{array}$ & $\begin{array}{l}85 \text { Caucasian MMT } \\
\text { patients }\end{array}$ & $\begin{array}{l}D R D 2 \text { rs } 6275 \text { was associated } \\
\text { with methadone dose and time } \\
\text { to reach maximum dose; } \\
p=0.016 \text { and } 0.005 \text { for average } \\
\text { and maximum dose, } \\
\text { respectively (exact figures not } \\
\text { shown in the original) }\end{array}$ \\
\hline & $\begin{array}{l}\text { Hung et } \\
\text { al. }[55]\end{array}$ & $\begin{array}{l}\text { 321 Han Chinese } \\
\text { MMT patients: } 92 \text { low } \\
\text { dose (<55 mg/day); } \\
150 \text { medium dose } \\
\text { (55-99 mg/day); } 79 \\
\text { high dose (100- } \\
150 \mathrm{mg} / \text { day) }\end{array}$ & $\begin{array}{l}D R D 2 \text { variability was } \\
\text { associated with methadone dose } \\
\text { requirements, } D R D 2-214 \mathrm{~A}>\mathrm{G} \\
\text { or } 939 \mathrm{C}>\mathrm{T} \text { allele had a twofold } \\
\text { chance of requiring a lower } \\
\text { methadone dose than non- } \\
\text { carriers }(p=0.001)\end{array}$ \\
\hline & $\begin{array}{l}\text { Bawor et } \\
\text { al. [69] }\end{array}$ & $\begin{array}{l}240 \text { MMT patients } \\
\text { (85\% of European } \\
\text { origin). Methadone } \\
\text { dose } \\
89.5 \pm 60.8 \mathrm{mg} / \text { day. R } \\
167(97.5 \pm 67.5), \mathrm{NR} \\
73(71.2 \pm 35.9)\end{array}$ & $\begin{array}{l}\text { The genetic variants were not } \\
\text { significantly associated with } \\
\text { continued opioid use: OR } 1.27 \\
95 \% \text { CI } 0.511-3.182 ; p=0.603\end{array}$ \\
\hline & $\begin{array}{l}\text { Huang et } \\
\text { al. [70] }\end{array}$ & $\begin{array}{l}138 \text { male Taiwanese } \\
\text { heroin addicts in } \\
\text { MMT } \\
(56.8 \pm 24.8 \mathrm{mg} / \mathrm{day} \\
\text { range } 3-140)\end{array}$ & $\begin{array}{l}D R D 2 \text { Taq1 B genotype was not } \\
\text { associated with methadone use } \\
\text { requirements }\end{array}$ \\
\hline & $\begin{array}{l}\text { Levran } \\
\text { et al. } \\
{[60]}\end{array}$ & $\begin{array}{l}227 \text { Israeli patients } \\
\text { undergoing stable } \\
\text { MMT } \\
(141 \pm 51 \mathrm{mg} / \text { day })\end{array}$ & $\begin{array}{l}\text { The two SNPs were associated } \\
\text { with lower methadone dose. } \\
A N K K 1 \text { rs } 7118900 \text { A allele } \\
\text { required lower methadone } \\
\text { doses than non-carriers } \\
(119 \pm 57.1,128.5 \pm 51.7 \text { vs. } \\
146.2 \pm 50.1 ; p=0.028) . D R D 2 \\
\text { rs } 2283265 \text { T allele required }\end{array}$ \\
\hline
\end{tabular}


lower methadone doses than non-carriers (121.2 \pm 51.4 , $128.2 \pm 53.2$ vs. $144.4 \pm 50.4$; $p=0.0496$, non-adjusted)

238 Caucasian MMT patients. Median methadone daily dose Oneda et $125 \mathrm{mg}$ (range 3$\beta$ Arrestin2 al. [76] $430 \mathrm{mg}$ ). Low-dose R 97 (37\%); high-dose R 78 (33\%); NR 73 $(31 \%)$

91 Caucasian MMT

de Cid et patients: 68R al. [80]

$(106.27 \pm 70.96) ; 23$

NR $(90.00 \pm 49.86)$

Homozygous for rs3786047, rs 1045280 and rs2036657 were more probably NR (48 vs. 29 and $23 \% ; p=0.01 ; 47$ vs. 29 and $25 \% ; p=0.002 ; 47$ vs. 29 and $25 \% ; p=0.002$ respectively)

Carriers of the CCGCCG haplotype of the subset formed by rs7127507, rs1967554, rs11030118, rs988748, rs2030324, and rs11030119 were at higher risk of being NR $4 / 42$ vs. 1/135 (corrected $p=0.0234$ )

Of $13 B D N F$ SNPs analysed, three non-coding $B D N F$ SNPs were associated with methadone dose. Lower methadone dose was $125.1 \pm 44.9$ (CC carriers of rs 1491850) vs. highest methadone dose $158.7 \pm 47.8$ (CC carriers of rs10835210)

240 MMT patients (85\% of European Bawor et origin). Methadone al. [69] dose

$89.5 \pm 60.8 \mathrm{mg} /$ day. $\mathrm{R}$ $167(97.5 \pm 67.5) ; \mathrm{NR}$ $73(71.2 \pm 35.9)$

NTRK2

Levran et al. [60]

227 Israeli patients undergoing stable MMT

$(141 \pm 51 \mathrm{mg} /$ day $)$
72 MMT patients

Levran et al. [82]
(Israeli population with Caucasian and Middle Eastern ancestry)
The genetic variants were not significantly associated with continued opioid use (OR 1.37, 95\% CI 0.792-2.371; $p=0.264$ )

Carriers of one or two of the variant $\mathrm{C}$ alleles of the rs2289658 SNP require relatively higher methadone doses (168 mg) than noncarriers $(143 \mathrm{mg})$. Carriers of two A alleles of rs2120266 require relatively higher methadone doses $(191 \mathrm{mg})$ than non-carriers

The mean daily methadone doses in subjects homozygous for the variant $\mathrm{T}$ allele (81.7 $\mathrm{mg}$ ) were lower than those of the heterozygotes and the non-carriers (140 and $153 \mathrm{mg}$, respectively) $(p=0.0002$ with recessive 


\begin{tabular}{|c|c|c|c|}
\hline \multirow{2}{*}{$N G F B$} & & & mode) \\
\hline & $\begin{array}{l}\text { Levran } \\
\text { et al. } \\
\text { [60] }\end{array}$ & $\begin{array}{l}227 \text { Israeli patients } \\
\text { undergoing stable } \\
\text { MMT } \\
(141 \pm 51 \mathrm{mg} / \text { day })\end{array}$ & $\begin{array}{l}\text { Homozygosity (TT) for SNP } \\
\text { rs2239622 resulted in a } \\
\text { methadone mean dose ( } 122 \mathrm{mg} \text { ) } \\
\text { that was lower than the mean } \\
\text { dose of heterozygotes and non- } \\
\text { carriers ( } 140 \text { and } 146 \mathrm{mg}, \\
\text { respectively), but the } \\
\text { association only reached } \\
\text { borderline significance }\end{array}$ \\
\hline$A L D H 5 A 1$ & $\begin{array}{l}\text { Fonseca } \\
\text { et al. } \\
\text { [83] }\end{array}$ & $\begin{array}{l}169 \text { Caucasian } \\
\text { subjects in MMT ( } 89 \\
\text { R and } 43 \mathrm{NR}) . \mathrm{R} 83 \\
(109 \pm 71 \mathrm{mg} / \text { day); } \\
\text { NR } 33 \\
(71 \pm 45 \mathrm{mg} / \text { day })\end{array}$ & $\begin{array}{l}\text { Subjects carrying the } \mathrm{T} \text { variant } \\
\text { allele have a higher risk of } \\
\text { being NR to methadone } \\
\text { treatment ( } 62.8 \text { vs. } 37.2 \% \text {; } \\
p=0.0024)\end{array}$ \\
\hline $\begin{array}{l}\text { GRM6; } \\
\text { GRM8; } \\
\text { NRAA2; } \\
\text { CRY1; } \\
\text { MYOCD }\end{array}$ & $\begin{array}{l}\text { Fonseca } \\
\text { et al. } \\
{[58]}\end{array}$ & $\begin{array}{l}\text { 116 Caucasian MMT } \\
\text { patients: R } 83 \\
(100 \pm 68 \mathrm{mg} / \text { day }) \\
\text { NR } 33 \\
(78 \pm 43 \mathrm{mg} / \text { day })\end{array}$ & $\begin{array}{l}\text { Patients carrying the A allele at } \\
\text { rs } 1714984(M Y O C D) \text { had an } \\
\text { increased risk of being NR only } \\
\text { when they were also carriers of } \\
\text { the AG genotype at rs } 953741 \\
(G R M 6)(\text { OR } 10.83 ; 95 \% \mathrm{CI} \\
2.52-46.66 ; p=0.006)\end{array}$ \\
\hline KCNJ6 & $\begin{array}{l}\text { Lötsch et } \\
\text { al. [84] }\end{array}$ & $\begin{array}{l}85 \text { Caucasian subjects } \\
\text { in MMT }\end{array}$ & $\begin{array}{l}\text { The average daily dose of } \\
\text { methadone during the first year } \\
\text { was higher in the AA genotype } \\
(119.7 \pm 49.6 \mathrm{vs} \text {. } \\
77.5 \pm 26.2 \mathrm{mg} / \text { day; } p=0.003)\end{array}$ \\
\hline
\end{tabular}

AQ3

AQ4

\section{1. $\mu$ Opioid Receptor (OPRM1)}

Methadone, heroin, and morphine have high affinity for the $\mu$ receptor. The gene encoding the receptor, OPRM1, is located in chromosome 6 (6q24-q25) [41]. The most widely studied polymorphism in OPRM1 is an SNP in exon 1 (rs 1799971), involving a substitution $\mathrm{A} \rightarrow \mathrm{G}$ (A118G), which encodes an Asn40Asp amino acid substitution. The Asp40 residue results in a threefold increase in $\beta$-endorphin binding compared with the Asn40-containing protein (probably related to suppression of a potential glycosylation site in the $\mathrm{N}$ terminal region [42]) and differences in messenger RNA (mRNA) expression, with a decrease of 1.5 in the mRNA and tenfold lower receptor levels in the 
G118 allele compared with the A118 allele. The authors hypothesized this could indicate a defect in transcription or mRNA maturation [43]. Carriers of this variant have reduced agonist-induced receptor signalling efficacy as shown in the post-mortem brain [44], differences in signal response to agonists [45], and stronger cortisol response to receptor blockade by naloxone, with a reduced agonist effect of morphine-6-glucuronide [46]. Several authors have studied the influence of this gene on opioid addiction disorder, with controversial results. A recent meta-analysis indicated that the $\mathrm{G}$ allele has a protective effect in substance dependence, but no significant results have been detected for opioid use disorder [47]. This SNP has also been studied in terms of naltrexone response in alcohol use disorder and the doses required to achieve analgesia in pain treatment $[48,49,50,51,52]$. However, the influence of this SNP on MMT outcome remains unclear. An experimental study reported an association between the $118 \mathrm{G}$ variant and decreased miotic potency of $(R)$-methadone in healthy volunteers [53]. When this gene was evaluated in MMT subjects, one study [54] reported an epistatic interaction of the polymorphism with the transporter gene ATP-binding cassette subfamily B member $1(A B C B 1)$ and methadone dose. OPRM1 wild-type subjects plus $A B C B 1$ carriers of a haplotype variant required lower methadone doses than $A B C B 1$ wild-type carriers $(35 \pm 5$ vs. $180 \pm 65 \mathrm{mg} /$ day; $p<0.01)$. Similarly, when the SNP was assessed in combination with other genes involved in methadone pharmacokinetics, the A118G SNP was associated with the maximum methadone dose [55]. However, both studies had high-risk or type I errors as they did not control for multiple testing. In contrast, other authors have found no association between polymorphisms at OPRM1 alone and treatment response (based on heroin use) or with methadone doses $[54,55,56]$, indicating that the influence of this SNP may be modulated by other pharmacodynamic and pharmacokinetic factors. AQ5

Evaluations of other SNPs in OPRM1 have produced some controversial results. One study evaluating the SNP rs 10744287, previously associated with opioid addiction [57], found no association with MMT outcome (based on urine controls) [58]. Other authors evaluating the influence of other OPRMI SNPs on methadone adverse events (see Sect. 4.1.1) found no association with treatment response, methadone dose, or plasma concentrations [59].

Two studies recently described promising results regarding the influence of OPRM1 SNPs on methadone requirements and treatment outcome. Levran et al. [60] investigated 11 genes related to the opioid, dopamine, glutamate, and 
neurotrophin systems: 23 SNPs in the OPRM1 gene, and one SNP (rs558025), were associated with methadone dose, and carriers of the $\mathrm{G}$ allele required lower doses of methadone $(132.4 \pm 50.7$ vs. $147.4 \pm 49.7 \mathrm{mg} /$ day; $p=0.028$ in a dominant model). The authors controlled for SNP multiple testing, and the $p$ values were obtained by permutation analysis based on 40,000 replicates to allow for the fact that, for a given SNP, three modes of inheritance were tested (co-dominant, dominant, and recessive). Although the differences were statistically significant, they have little relevance in clinical practice. In a sample of opioid-dependent African American subjects, the SNP rs73568641 (of which the nearest gene-306 kilobases-is OPRM1) was associated with methadone dose. This association was replicated in the amount of morphine required to treat pain after surgery in a set of opioid-naïve African American children but was not observed in a Caucasian cohort [51]. Finally, 582 patients receiving methadone or buprenorphine/naloxone treatment were evaluated in terms of treatment response, based on the number of opioid-positive urine controls. A single haplotype, tagged by rs10485058, was significantly associated with patient urinalysis data in the methadone treatment group. The same SNP also predicted self-reported relapse rates in an independent population of Australian patients of European descent receiving opioid substitution therapy [61].

In light of the reviewed studies, it is not possible to draw clear conclusions about the influence of the OPRM1 gene on treatment response. Most studies had not been replicated, and several cases were not controlled by multiple testing $[54,55]$, so the risk of a type I error was high. Moreover, the samples were heterogeneous (e.g., Caucasian, Chinese, Israeli, and African American), and G allele frequencies vary according to ethnicity, ranging from 0.12 to $0.20 \mathrm{in}$ Whites (non-Hispanic, European descent), 0.19 to 0.24 in non-White Hispanics, and 0.01 to 0.04 in African Americans [62]. Furthermore, the frequency of the This allele has been is found in $40-50 \%$ of Asian populations [43]. Although evidence seems to suggest that polymorphisms at OPRM1 are crucial for opioid addiction, pain therapy, and methadone-related adverse events, there are no conclusive results with implications for MMT response or the dose of methadone required to achieve good outcomes.

\subsection{Delta Opioid Receptor (OPRD1)}

The OPRD1 gene, located in chromosome 1p36, encodes the delta opioid receptor (DOR), a G-protein-coupled receptor. This receptor has been 
implicated in reward, pain, addiction, and affective changes [63, 64]. Some authors have associated variants in OPRD1 with the risk of opioid addiction [65]. One study evaluating the involvement of six SNPS in the OPRD1 gene for an association with positive urine tests in patients receiving methadone and buprenorphine treatment reported that, in patients receiving methadone, carriers of CC genotype at rs678849 SNP were less likely to have opioid-positive urine tests than were heterozygous and non-carriers [66]. As the study included only a reduced sample of African Americans and was not replicated, it was not possible to establish a relationship between this gene and methadone response.

\subsection{Dopamine D2 Receptor (DRD2) and Ankyrin Repeat and Kinase Domain Containing 1 (ANKK1)}

The dopaminergic system is involved in the rewarding effects of opioids and drugs of abuse. Heroin increases dopamine concentrations in the reward areas of the brain (nucleus accumbens and caudate putamen). The $\mathrm{D}_{2}$ receptor gene (DRD2) is located in chromosome 11 (11q22-23). Polymorphisms in this gene have been associated with addiction [67].

Crettol et al. [56] analysed the synonymous polymorphism rs6277 (C957T) in a group of 238 heroin-dependent subjects on an MMT programme. The carriers of the 957CC genotype were more frequently non-responders with a shorter period of negative results in urine tests [56]. In a study [68] in 85 MMT patients, average and maximum daily methadone doses were significantly associated with rs6275 (C939T) SNP. The carriers of the T allele needed higher methadone doses and required a longer time to reach the maximum methadone dose than non-carriers, but the exact figures were not included in the original article. Hung et al. [55] described an association between methadone doses and two SNPS of the DRD2 gene, rs1799978 (A214G) and rs6275. In contrast, another study could not replicate the influence of rs1799978 on MMT outcome (measured by the continued use of illicit opioids) [69]. However, the sample size of the non-responder group was small, and significant differences in mean methadone doses between groups interfered with the results, as non-responders were treated with lower doses (difference of $26 \mathrm{mg}$ ). Another study [70] investigated whether DRD2 TaqIB polymorphisms were related to methadone dose and personality traits and reported that differences in genotypes were not linked to daily methadone dose. One further study [60], which assessed SNPs from the DRD2 and $A N K K 1$ genes in a sample of stable MMT patients, found two SNPs to be associated with differences in methadone dose: the rs7118900 at 
ANKK1 (non-synonymous) and rs2283265 at DRD2 (intronic). Carriers of the variant A allele of $A N K K 1$ rs7118900 and the variant T allele of DRD2 rs2283265 required lower methadone doses than non-carriers [60].

Finally, in the year 2000, an exploratory study found that rs1800497 (Taql A1), an allele located $10 \mathrm{~kb}$ from the $3^{\prime}$ region of the DRD2 in disequilibrium linkage (DL) with the SNP rs6277, appeared to be associated with MMT response [71]; this finding was not replicated in a smaller sample [72].

In conclusion, while multiple studies have analysed DRD2 genetic variability, participants have come from diverse ethnicities (even within the same publication but with no specific information given) and the aspects evaluated have varied (dose, illicit opioid use, time to reach maximum dose), which precludes the collection of useful data and comparison of results.

\subsection{Beta-Arrestin}

$\beta$-Arrestin 2 is a component of the G-protein-coupled receptor complex. It is involved in $\mu$ opioid and $D_{2}$ receptor signalling. It also regulates the number of functional receptors expressed on the neuron surface by desensitization and internalization of these $\mathrm{G}$ protein-coupled receptors [73]. $\beta$-Arrestin 2 knockout mice do not become morphine tolerant when compared with wild-type mice, and the impact of different opioid agonists varies depending on the activity of $\beta$ arrestin 2 protein [73]. Polymorphisms in the coding gene $\beta$-arrestin 2 have been associated with differential risk for developing cocaine and nicotine addiction $[74,75]$. Our literature search revealed only one study [76] that evaluated the influence on treatment outcome of genetic variability at $\beta$-arrestin 2 (ARRB2); results were based on random urine controls (non-responders were maintained at methadone doses $>120 \mathrm{mg}$ /day). The authors evaluated 238 subjects receiving MMT and described a haplotype block that was associated with risk for poor response. Homozygosity for the variant allele at rs3786047, rs 1045280, and rs2036657 was associated with a non-responding phenotype. However, none of these SNPs induced changes in the final protein, and replication studies are lacking, which makes it difficult to explain the mechanism involved.

\subsection{Neurotrophins}

Neurotrophins are a protein family essential for central nervous system development; they are also involved in the survival and regeneration of 
damaged neurons, learning, memory, and brain plasticity [77].

Brain-derived neurotrophic factor (BDNF), a member of the nerve growth factor-related family of neurotrophins, is widely expressed in the adult mammalian brain, and evidence indicates that it may be involved in the mechanisms underlying substance abuse $[78,79]$.

An exploratory study in 91 subjects receiving MMT assessed $B D N F$ genetic variability, analysing 21 SNPs across the $B D N F$ genomic region. Haplotype block analysis showed a low-frequency haplotype (2.7\%) that was more common in the non-responder group [80]. Another study analysed $13 B D N F$ SNPs, of which three non-coding SNPs (rs10835210, rs7934165, and rs1491850) were associated with methadone doses and hypothesized to play a regulatory function [60]. The same study analysed 15 SNPs at the neurotrophic receptor tyrosine kinase 2 (NTRK2) gene; six intronic SNPs (rs2120266, rs2289658, rs4358872, rs1948308, rs2378676, and rs4877900) were found to be associated with methadone dose. A possible association between BDNF G196A (rs6265) and MMT outcome was evaluated using urine to assess treatment response in a sample of 240 patients but the variant was not associated with poor treatment outcomes [69]. Levran et al. [60] studied the same SNP but found no association even though they included a different population ancestry (Israeli).

Nerve growth factor $\beta$ polypeptide $(N G F B)$ could play a key role in opioid treatment as it has been associated with the expression of the DOR in the cell membrane [81]. Genotypes of 14 SNPs of $N G F B$ were analysed for involvement in response to MMT, and a significant difference was observed in methadone doses required depending on the genotype at rs2239622: the mean daily methadone doses in subjects homozygous for the variant $\mathrm{T}$ allele $(81.7 \mathrm{mg})$ were lower than those of the heterozygotes and the non-carriers (140 and $153 \mathrm{mg}$, respectively) [82]. A later study did not confirm this association, although homozygous subjects required lower doses than heterozygotes and non-carriers (122 vs. 140 vs. $146 \mathrm{mg}$ ); however, the differences were nonsignificant, and the clinical significance of the variation was minimal [60].

The evidence found for genes encoding for neurotrophins has limitations similar to those described in previous sections. We found few studies evaluating neurotrophic factors (three for $B D N F$, one for NTRK2, and two for $N G F B$ ), and those we did find were conducted in patients of different ethnicity, and none 
replicated results in the same SNP. In cases describing significant differences, either the haplotype was low frequency [80] or the differences in the daily dose of methadone had no clinical relevance [82]. For these reasons, we cannot conclude that the genetic variability in genes coding for neurotrophins could clearly determine methadone response.

\subsection{Succinic Semialdehyde Dehydrogenase ( $\left.A L D H_{5} A 1\right)$}

The succinic semialdehyde dehydrogenase enzyme SSADH or ALDH5A1 is responsible for the transformation of succinic semialdehyde to succinic acid, which then enters the Krebs cycle. Succinic semialdehyde is the metabolite of gamma-aminobutyric acid (GABA), an inhibitory neurotransmitter of the brain. In addition, it is the precursor and metabolite of gamma hydroxybutyric acid (GHB). Our group genotyped a genetic variant in ALDH5A1 (rs2760118; $\mathrm{cC} 538 \mathrm{~T}$ ) and found that subjects carrying the variant $\mathrm{T}$ allele had a higher risk of being non-responders to methadone treatment ( 62.8 vs. $37.2 \%)$. This variant involves an amino acid substitution and results in a considerable reduction in enzyme activity (83\%). The possible explanation for such an association could be a reduction in enzyme activity, which would increase endogenous GHB and GABA levels and thus induce symptoms such as sedation and impaired psychomotor performance, neuropsychological adverse events that could be responsible for a greater propensity to relapse in genetically predisposed patients [83]. Although the results appear very promising, the small sample size and lack of replication studies mean that results should be interpreted with caution.

\subsection{Other Genes}

Based on the results of a GWAS by Nielsen et al. [57] aimed at detecting new loci associated with opioid dependence, our investigation group [58] performed an association study to evaluate a possible association between response to MMT and polymorphisms of genes involved in opioid dependence. We found an association between MMT response status and genetic variability in the cryptochrome 1 ( $C R Y 1)$ gene, which is involved in circadian rhythms. In addition, we also described an epistatic effect between the genes coding for the transcription factor myocardin $(M Y O C D)$ and the metabotropic glutamate receptor 6 (GRM6) [58].

Another gene studied for its possible association with MMT is potassium voltage-gated channel subfamily $\mathrm{J}$ member 6 (KCNJ6), which encodes for 
potassium inwardly rectifying channels (Kir3.2, GIRK2) involved in opioid receptor transmission. The authors genotyped 85 patients receiving MMT, 352 pain patients receiving opioid treatment, and 51 healthy controls. The mean dose of methadone during the first year was higher in patients with the rs2070995 AA genotype $(119.7 \pm 49.6$ vs. $77.5 \pm 26.2 \mathrm{mg}$ /day; $p=0.003)$. Moreover, a trend, but not a significant result, was observed in patients treated with opioids for analgesia in the carriers of the AA genotype $(p=0.093)$ [84].

\section{Pharmacokinetic Genetic Variability}

It has been classically described that methadone is extensively metabolized in the liver, mainly by CYP3A4. Both in vitro and in vivo studies have shown that the isoenzymes of cytochrome P450, CYP3A4, CYP2D6, CYP2B6, and CYP2C19, are involved in methadone metabolism [25, 85, 86, 87, 88, 89]. The pharmacokinetics of methadone are also influenced by the activity of a membrane transporter, P-glycoprotein, a trans-membrane protein expressed in tissues with barrier function (intestine, brain). Its activity in intestines and the blood-brain barrier (BBB) has shown relevance in defining methadone concentrations [38], and a recent review of clinical interaction studies discussed the influence of P-glycoprotein in methadone brain access [89].

Genetic variability in genes coding for metabolizing enzymes and transporters has been extensively studied. Overall, variability at this level can influence enzyme activity, changing methadone plasma concentrations. It should be taken into account that some of these enzymes display stereoselectivity towards one of the enantiomers, and differences in their activity alter the $(R) /(S)$-methadone ratio and lead to variations in therapeutic response and adverse events. Table 2 summarizes the genes involved in the metabolism and transport of methadone.

\section{Table 2}

Main studies assessing pharmacokinetic genetic variability and its influence in methadone maintenance treatment (MMT) outcome

\begin{tabular}{|r|l|l|l|}
\hline Study & $\begin{array}{l}\text { Sample } \\
\text { characteristics }\end{array}$ & Gene(s)/SNP(s) & Results \\
\hline Metabolizing genes (CYP) & & $\begin{array}{l}\text { Different phenotypes } \\
\text { associated with } \\
\text { methadone plasma } \\
\text { concentrations: for }(R)- \\
(p=0.024),(S)-\end{array}$ \\
\hline Eap et & 235 MMT subjects: 18 & CYP2D6 & \\
\hline
\end{tabular}


CYP2B6;

CYP2C9;

CYP2C19
CYP2B6 genotype influences $(S)$-methadone and, to a lesser extent, $(R)$-methadone plasma levels (105 vs. 122 vs. $203 \mathrm{ng} \cdot \mathrm{kg} / \mathrm{ml}$ for the noncarriers of allele $* 6$, heterozygous and homozygous, respectively $(p=0.0004) . C Y P 2 C 9$ and CYP2C19 genotypes do not influence methadone plasma levels

245 Caucasian MMT patients (divided in low-dose R, high-dose

Crettol et al. $R$, high-dose NR).

[92] Mean methadone dose $134 \pm 82 \mathrm{mg}$ (range $3-$ $430 \mathrm{mg} /$ day)

CYP1A2;

CYP3A4;

CYP3A5;

CYP2B6;

CYP2D6;

CYP2C9;

CYP2C19

$C Y P 3 A 4, C Y P 2 B 6$ and, to a minor extent, $C Y P 2 D 6$ were involved in methadone metabolism

\begin{tabular}{l|l}
$\quad$ Coller & 51 MMT subjects (45 \\
et al. & White, 5 indigenous \\
{$[108]$} & Australian, 1 Asian)
\end{tabular}

[108]

\begin{tabular}{l|l} 
& 105 Caucasian MMT \\
Fonseca & patients. R 76 dose: \\
et al. & $109 \pm 68 ;$ NR 29 dose: \\
[93] & $72 \pm 43$
\end{tabular}

\section{Han Chinese}

MMT patients. 92 low

\begin{tabular}{l|l}
$\begin{array}{l}\text { Hung } \\
\text { et al. }\end{array}$ & $\begin{array}{l}\text { dose (<55 mg/day); } \\
\text { [55] }\end{array}$ \\
& $\begin{array}{l}\text { (55-99 mg/day }) ; 79 \\
\text { high dose (100- } \\
150 \mathrm{mg} / \text { day })\end{array}$
\end{tabular}

366 Han Chinese

MMT patients.

\begin{tabular}{l|l}
\multicolumn{1}{c}{ Wang } & Methadone dose \\
et al. & $54.7 \pm 28.1 \mathrm{mg} /$ day. \\
[98] & $\begin{array}{l}\text { Methadone plasma } \\
\text { concentrations }\end{array}$ \\
& $193.07 \pm 121.76 \mathrm{ng} / \mathrm{ml}$
\end{tabular}

178 Taiwanese MMT patients (R 62 and NR
CYP3A5;

CYP2B6;

CYP2D6;

CYP2C9;

CYP2C19

No influence of any polymorphism in $(R)-,(S)$, and $(R, S)$-methadone clearance

CYP2D6 metabolizing phenotype differences were found, higher probability of being NR in the group of UM $(p=0.032)$

rs3745274 (G516T) SNP was associated with differences in methadone doses: low-dose patients were more likely to carry the TA and TG haplotypes than were medium- and high-dose methadone patients $(p<0.001)$

rs10403955, rs3745274, rs2279345, and rs 707265 were associated with a higher clearance, a lower plasma concentration, and a lower C/D ratio of (S)methadone $(p=0.0017)$

Methadone maintenance dose, CYP2B6 rs2279343 


\begin{tabular}{|c|c|c|c|}
\hline $\begin{array}{r}\text { Lee et } \\
\text { al. [102] }\end{array}$ & $\begin{array}{l}\text { 116). Methadone daily } \\
\text { dose } \\
50.8 \pm 30.5 \mathrm{mg} / \text { day } \\
\text { (range } 5-250)\end{array}$ & $\begin{array}{l}\text { CYP2B6; } \\
\text { CYP2C19 }\end{array}$ & $\begin{array}{l}(785 \mathrm{G}) \text { allele, and } A B C B 1 \\
\text { rs2032582 ( } 2677 \mathrm{~T}) \text { allele } \\
\text { had positive effects on the } \\
\text { methadone plasma } \\
\text { concentration }\end{array}$ \\
\hline $\begin{array}{l}\text { Levran } \\
\text { et al. } \\
\text { [94] }\end{array}$ & $\begin{array}{l}74 \text { Israeli MMT } \\
\text { patients. Mean dose } \\
140 \pm 52 \mathrm{mg} / \text { day } \\
\text { (range } 3-260 \text { ) }\end{array}$ & $\begin{array}{l}\text { CYP3A4; } \\
\text { CYP2B6; } \\
\text { CYP2D6 }\end{array}$ & $\begin{array}{l}C Y P 2 B 6 \text { genetic } \\
\text { variability was involved } \\
\text { in MMT dose } \\
\text { requirements: rs } 3745274 \\
\text { GG carriers required } \\
\text { higher doses of } \\
\text { methadone }(150.3 \pm 8.1) \\
\text { than GT }(128.6 \pm 9.1) \text { and } \\
\text { TT }(96.3 \pm 15.3) \\
(p=0.048) \text {. rs } 2279343 \\
\text { AA carriers required } \\
\text { higher doses of } \\
\text { methadone }(151.4 \pm 8.4) \\
\text { than AG }(132.6 \pm 8.9) \text { and } \\
\text { GG }(88.3 \pm 11.9), \\
(p=0.012)\end{array}$ \\
\hline $\begin{array}{l}\text { Dennis } \\
\text { et al. } \\
{[103]}\end{array}$ & $\begin{array}{l}\text { Meta-analysis of } \\
\text { seven articles }\end{array}$ & СYР $2 B 6$ & $\begin{array}{l}\text { Homozygous for the } \\
C Y P 2 B 6^{*} 6 \text { genotype have } \\
\text { higher trough }(R) \text { and }(S) \\
\text { methadone plasma } \\
\text { concentrations, but no } \\
\text { influence on MMT } \\
\text { response }\end{array}$ \\
\hline $\begin{array}{l}\text { Wang } \\
\text { et al. } \\
\text { [96] }\end{array}$ & $\begin{array}{l}366 \text { Han Chinese } \\
\text { MMT patients. } \\
\text { Methadone dose } \\
54.7 \pm 28.1 \mathrm{mg} / \mathrm{day} . \\
\text { Methadone plasma } \\
\text { concentrations } \\
193.07 \pm 121.76 \mathrm{ng} / \mathrm{ml}\end{array}$ & $\begin{array}{l}\text { CYP 2B6; } \\
\text { CYP } 3 A 4 ; \\
\text { CYP } 2 C 19\end{array}$ & $\begin{array}{l}\text { SNPs on } C Y P 2 B 6 \text { were } \\
\text { associated with plasma } \\
(S) \text {-methadone } \\
\text { concentration; SNPs on } \\
C Y P 3 A 4 \text { were associated } \\
\text { with withdrawal } \\
\text { symptoms and side } \\
\text { effects; and SNPs on } \\
C Y P 2 C 19 \text { were associated } \\
\text { with methadone dose }\end{array}$ \\
\hline $\begin{array}{l}\text { Tsai et } \\
\text { al. [101] }\end{array}$ & $\begin{array}{l}366 \text { Han Chinese } \\
\text { MMT patients. } \\
\text { Methadone dose: } \\
54.7 \pm 28.1 \mathrm{mg} / \text { day. } \\
\text { Methadone plasma } \\
\text { concentrations } \\
193.07 \pm 121.76 \mathrm{ng} / \mathrm{ml}\end{array}$ & $\begin{array}{l}\text { CYP2B6; } \\
\text { CYP } 3 A 4 ; \\
\text { СYР2C19 }\end{array}$ & $\begin{array}{l}\text { Methadone dose was } \\
\text { influenced by CYP } 2 \text { C19 } \\
\text { gene dose in patients with } \\
\text { negative urine controls } \\
\text { but not in those with } \\
\text { positive results }\end{array}$ \\
\hline $\begin{array}{l}\text { Dobrinas } \\
\text { et al. } \\
\text { [100] }\end{array}$ & $\begin{array}{l}\text { From } 276 \text { Caucasian } \\
\text { MMT patients, } 12 \text { and } \\
35 \text { selected } \\
\text { individuals with high } \\
(S) \text {-methadone plasma } \\
\text { exposure and low }(S)- \\
\text { methadone plasma } \\
\text { exposure, respectively }\end{array}$ & CYP2B6 & $\begin{array}{l}\text { High concentrations of } \\
(S) \text {-methadone-high } \\
\text { levels of rs } 35303484 \\
\text { Low concentrations of } \\
(S) \text {-methadone-low } \\
\text { levels of rs } 3745274 \text { and } \\
\text { rs2279344; and high } \\
\text { levels of rs3211371 }\end{array}$ \\
\hline & & & A modest correlation was \\
\hline
\end{tabular}


81 stable patients et al.

Mouly

[21]
(85.2\% Caucasians;

9.9 Africans; $4.9 \%$

Asians) divided into quartiles with respect to the median daily dose
CYP2B6;

CYP $3 A 5$

CYP2C19;

CYP2D6 observed between

liver/intestinal CYP3A4 activity and methadone dose at steady state, but none of the genetic polymorphisms showed influence in the methadone dose

Transporter gene $(A B C B 1)$

\begin{tabular}{|c|c|c|c|}
\hline $\begin{array}{l}\text { Coller } \\
\text { et al. } \\
\text { [115] }\end{array}$ & $\begin{array}{l}60 \text { opioid-dependent } \\
\text { subjects in MMT and } \\
60 \text { healthy controls }\end{array}$ & $\begin{array}{l}\text { rs9282564 } \\
\text { (A61G); } \\
\text { rs2229109 } \\
\text { (G1199A); } \\
\text { rs1128503 } \\
\text { (C1236T); } \\
\text { rs2032582 } \\
\text { (G2677TorA); } \\
\text { rs1045642 } \\
\text { (C3435T) }\end{array}$ & $\begin{array}{l}\text { No influence on disease } \\
\text { status. } A B C B 1 \text { genotype } \\
\text { influenced in the } \\
\text { methadone dose required: } \\
\text { AGCTT genotype } \\
\text { associated with lower } \\
\text { doses }\end{array}$ \\
\hline $\begin{array}{l}\text { Crettol } \\
\text { et al. } \\
\text { [119] }\end{array}$ & $\begin{array}{l}245 \text { Caucasian MMT } \\
\text { patients (low-dose R, } \\
\text { high-dose R, high- } \\
\text { dose NR). Mean } \\
\text { methadone dose } \\
134 \pm 82 \mathrm{mg} \text { (range 3- } \\
430 \text { ) }\end{array}$ & $\begin{array}{l}\text { rs } 1045642 \\
(\mathrm{C} 3435 \mathrm{~T})\end{array}$ & $\begin{array}{l}\text { Lower plasma } \\
\text { concentrations were found } \\
\text { in the TT carriers, but no } \\
\text { influence on dose or } \\
\text { response }\end{array}$ \\
\hline $\begin{array}{l}\text { Levran } \\
\text { et al. } \\
\text { [116] }\end{array}$ & 98 MMT patients & $\begin{array}{l}\text { rs1045642 } \\
(\mathrm{C} 3435 \mathrm{~T}) ; \\
\text { rs6949448; } \\
\text { rs2235067; } \\
\text { rs2032583; } \\
\text { rs2032582 } \\
\text { (G2677TorA); } \\
\text { rs1128503 } \\
\text { (C1236T); } \\
\text { rs1922242; } \\
\text { rs2520464; } \\
\text { rs3789243 }\end{array}$ & $\begin{array}{l}\text { Patients with TT-TT-TT } \\
\text { genotype pattern of } \\
\text { rs1045642, rs } 2032582 \text { and } \\
\text { rs1128503 have more } \\
\text { chance to require higher } \\
\text { doses of methadone }\end{array}$ \\
\hline $\begin{array}{l}\text { Fonseca } \\
\text { et al. } \\
\text { [93] }\end{array}$ & $\begin{array}{l}105 \text { Caucasian MMT } \\
\text { patients. R } 76 \text { dose } \\
109 \pm 68 ; \text { NR } 29 \text { dose } \\
72 \pm 43\end{array}$ & $\begin{array}{l}\text { rs } 1045642 \\
\text { (C3435T) }\end{array}$ & $\begin{array}{l}\text { No association with } \\
\text { response, methadone dose, } \\
\text { or plasma concentrations }\end{array}$ \\
\hline $\begin{array}{l}\text { Hung } \\
\text { et al. } \\
\text { [55] }\end{array}$ & $\begin{array}{l}321 \text { Han Chinese } \\
\text { MMT patients }(92 \text { low } \\
\text { dose; } 150 \text { medium } \\
\text { dose; } 79 \text { high dose) }\end{array}$ & $\begin{array}{l}\text { rs } 1045642 \\
\text { (C3435T) }\end{array}$ & $\begin{array}{l}\text { Associated with } \\
\text { differences in methadone } \\
\text { doses }\end{array}$ \\
\hline $\begin{array}{l}\text { Barratt } \\
\text { et al. }\end{array}$ & $\begin{array}{l}119 \text { Caucasian MMT } \\
\text { patients }\end{array}$ & $\begin{array}{l}\text { rs9282564 } \\
\text { (A61G); } \\
\text { rs2229109 } \\
\text { (G1199A); } \\
\text { rs1128503 } \\
\text { (C1236T); }\end{array}$ & $\begin{array}{l}\text { Wild-type } O P R M 1 \\
\text { subjects, the carriers of an } \\
A B C B 1 \text { variant haplotype } \\
\text { required significantly } \\
\text { lower doses of methadone } \\
\text { than } A B C B 1 \text { wild-types } \\
\text { Among subjects with the }\end{array}$ \\
\hline
\end{tabular}




\begin{tabular}{|c|c|c|c|}
\hline [54] & & $\begin{array}{l}\text { rs2032582 } \\
\text { (G2677TorA); } \\
\text { rs } 1045642 \\
(\mathrm{C} 3435 \mathrm{~T})\end{array}$ & $\begin{array}{l}\text { most common } A B C B 1 \\
\text { haplotype, the } 118 \mathrm{~A} / \mathrm{G} \\
\text { genotype was associated } \\
\text { with higher methadone } \\
\text { plasma concentrations }\end{array}$ \\
\hline $\begin{array}{r}\text { Lee et } \\
\text { al. [102] }\end{array}$ & $\begin{array}{l}178 \text { Taiwanese MMT } \\
\text { patients (R } 62 \text { and NR } \\
116 \text { ). Methadone daily } \\
\text { dose } \\
50.8 \pm 30.5 \mathrm{mg} / \text { day } \\
\text { (range } 5-250 \text { ) }\end{array}$ & $\begin{array}{l}\text { rs2032582 } \\
\text { (G2677TorA) }\end{array}$ & $\begin{array}{l}\text { Methadone maintenance } \\
\text { dose, } C Y P 2 B 6785 \mathrm{G} \\
\text { allele, and } A B C B 12677 \mathrm{~T} \\
\text { allele had positive effects } \\
\text { on the methadone plasma } \\
\text { concentration }\end{array}$ \\
\hline $\begin{array}{l}\quad \text { Bart } \\
\text { et al. } \\
\text { [118] }\end{array}$ & $\begin{array}{l}206 \text { MMT patients ( } 76 \\
\text { Hmong and } 130 \text { non- } \\
\text { Hmong) }\end{array}$ & $\begin{array}{l}\text { rs2032582 } \\
\text { (G2677TorA) }\end{array}$ & $\begin{array}{l}\text { Hmong ethnicity reduced } \\
\text { CL/F by approximately } \\
30 \% \text { and the rs } 2032582 \\
\text { GG genotype was } \\
\text { associated with a } 20 \% \\
\text { reduction in } \mathrm{CL} / \mathrm{F}\end{array}$ \\
\hline $\begin{array}{l}\text { Dennis } \\
\text { et al., } \\
2014 \\
{[103]}\end{array}$ & $\begin{array}{l}\text { Meta-analysis of } \\
\text { seven studies }\end{array}$ & & $\begin{array}{l}\text { No significant association } \\
\text { between the } A B C B 1 \\
\text { polymorphism and the } \\
\text { trough }(R),(S) \\
(R, S) \text { - plasma } \\
\text { concentrations, methadone } \\
\text { dose, or methadone } \\
\text { response }\end{array}$ \\
\hline $\begin{array}{l}\text { Zahari } \\
\text { et al. } \\
\text { [117] }\end{array}$ & $\begin{array}{l}148 \text { MMT males. } \\
\text { Methadone dose } \\
72.70 \pm 28.25 \mathrm{mg} / \text { day } \\
\text { (range } 20-160)\end{array}$ & $\begin{array}{l}\text { rs } 1128503 \\
\text { (C1236T); } \\
\text { rs2032582 } \\
\text { (G2677TorA); } \\
\text { rs1045642 } \\
(\mathrm{C} 3435 \mathrm{~T})\end{array}$ & $\begin{array}{l}\text { Association of CGC/TTT } \\
\text { diplotype (1236C }>\mathrm{T}, \\
2677 \mathrm{G}>\mathrm{T} / \mathrm{A} \text {, and } \\
3435 \mathrm{C}>\mathrm{T} \text { ) with dose- } \\
\text { adjusted serum } \\
\text { methadone. Patients with } \\
\text { CGC/TTT diplotype had } \\
\text { 32.9\% higher dose- } \\
\text { adjusted serum methadone }\end{array}$ \\
\hline \multicolumn{4}{|c|}{ Other genes/SNPs } \\
\hline $\begin{array}{l}\text { Yang } \\
\text { et al. } \\
\text { [120] }\end{array}$ & $\begin{array}{l}344 \text { Han Chinese } \\
\text { MMT patients }\end{array}$ & rs 17180299 & $\begin{array}{l}\text { This SNP would influence } \\
\text { the regulation of plasma } \\
(R) \text {-methadone through } \\
\text { epigenetic histone } \\
\text { modification of } \\
\text { H3K9me3. This SNP } \\
\text { accounted for } 9.541 \% \text { of } \\
\text { the variation in the plasma } \\
\text { concentration of the }(R)- \\
\text { methadone }\end{array}$ \\
\hline \multicolumn{4}{|c|}{$\begin{array}{l}C / D \text { concentration-to-dosage, } C L / F \text { apparent total clearance, } C Y P \text { cytochrome } \\
\text { P450, } E M \text { extensive metabolizers, } M M T \text { methadone maintenance treatment, } N R \\
\text { non-responders, } P M \text { poor metabolizers, } R \text { responders, SNPs single nucleotide } \\
\text { polymorphisms, } U M \text { ultra-rapid metabolizers }\end{array}$} \\
\hline
\end{tabular}




\section{1. $\mathrm{CYP}_{3} \mathrm{~A}_{4}$}

CYP3A4 has been shown to be involved in the formation of 2-ethylidene-1,5dimethyl-3,3-diphenylpyrrolidine (EDDP) [90] in a non-enantioselective way [91]. The activity of this enzyme varies widely between individuals and can be affected by health status and environmental aspects. Genetic variability does not affect the pharmacokinetics of methadone in any significant manner, and most SNPs occur with low allelic frequencies. Crettol et al. [92] conducted an in vivo study and reported that the carriers of the $C Y P 3 A 4 * 1 B$ (rs2740574) variant presented a 1.4-fold increase for $(S)$-methadone and a 1.1-fold increase for $(R)$ methadone concentrations, although this group was more likely to take lower doses of methadone. A French study assessed the influence of environmental and genetic factors (liver/intestinal CYP3A4 activity and polymorphisms of the OPRM1, DRD2, catechol-O-methyltransferase [COMT], $A B C B 1, C Y P 2 B 6$, $C Y P 3 A 5, C Y P 2 C 19$, and CYP2D6 genes) on methadone doses. Although they observed a modest correlation between liver/intestinal CYP3A4 activity and methadone dose at steady state, none of the genetic polymorphisms was shown to play a role with respect to dose [21]. In addition, a study by Fonseca et al. [93] and an additional analysis by Levran et al. [94] in 74 Israeli patients receiving MMT found no association between $C Y P 3 A 4$ and methadone doses.

These results indicate that the genetic variability of the CYP $3 A 4$ gene has little influence on MMT, but its activity could be changed by environmental factors such as concomitant medication.

\section{2. $C Y P 2 B 6$}

In vitro and in vivo studies have reported that CYP2B6 is a contributor to methadone metabolism in different ethnic populations, with stereoselectivity towards $(S)$-methadone $[95,96]$. Multiple SNPs within the CYP2B6 gene (19q13.2), with varying prevalence in allele frequency depending on the ethnicity of the population studied, have been described [97]. Individuals carrying the rs3745274 and rs2279343 SNPs $\left(C Y P 2 B 6^{*} 6 / * 6\right.$ homozygous individuals) showed low CYP2B6 protein levels, resulting in changes in $(S)$ methadone plasma concentrations and only weak $(R)$-methadone plasma concentrations $[25,92,98]$. One study including healthy volunteers with different CYP2B6 genotypes evaluated differences in methadone enantiomers after single doses of oral and intravenous methadone. The metabolism of both enantiomers was reduced in $C Y P 2 B 6^{*} 6$ carriers and increased in $C Y P 2 B 6^{*} 4$ 
(rs3745274 and rs2279343) carriers [99].

In terms of the influence of $C Y P 2 B 6$ gene on the concentrations of $(S)$ methadone, some polymorphisms have been associated with plasma levels of this enantiomer. A subsample of patients receiving methadone treatment underwent a resequencing of the CYP2B6 gene (12 had a high plasma concentration and 35 low) and were then compared with the rest of the subjects. The authors found a marked prevalence of the rs35303484 (*11; Ac136G; M46V) polymorphism in the high $(S)$-methadone concentration group; the low $(S)$-methadone group exhibited a lower frequency of the rs3745274 (*9; Gc516T; Q172H), rs2279344 (c822 +G183A), and rs8192719 (c1294+ C53T) polymorphism and a high frequency of the rs3211371 (*5; Cc1459T; R487C) polymorphism [100]. Another study [101] evaluated the influence of CYP2B6 and its interaction with the nuclear receptor subfamily 1 group I member 2 (PXR) gene (which regulates the expression of the CYP450s) and showed that the combination could contribute to significant differences in $(S)$-methadone concentrations. When comparing different combinations of rs 1464603 , rs1464603, and rs2472681 at $P X R$ and rs2279345, rs707265, and rs2279345 at CYP2B6, a genotype combination was produced that related to lower concentrations of $(S)$-methadone: $146.57 \pm 102.47 / 141.83 \pm 98.38 / 71.06 \pm 44.08$ $(p=0.0003), 139.76 \pm 99.01 / 143.95 \pm 99.50 / 71.06 \pm 44.08(p=0.0007)$, and $153.72 \pm 101.85 / 138.93 \pm 98.19 / 73.60 \pm 53.62(p=0.001)$, respectively.

Clinical studies with opioid-dependent subjects receiving MMT had mixed results. Three reported no influence of the CYP2B6 gene in terms of MMT response $[25,92,93]$, whereas another three showed differences in the methadone dose requirements depending on the genotype $[55,94,102]$.

One meta-analysis of seven articles reporting data on possible associations between a $C Y P 2 B 6^{*} 6$ polymorphism and methadone dose, plasma concentrations, and MMT outcomes observed that patients homozygous for the $C Y P 2 B 6^{*} 6$ genotype had higher trough $(R)$ - and $(S)$-methadone plasma concentrations but found no differences in terms of methadone dose or treatment response [103].

The data currently available indicates that the influence of the CYP2B6 gene on methadone pharmacology may be related not only to a single polymorphism $\left(C Y P 2 B 6^{*} \sigma\right)$ but also to different interacting effects of multiple polymorphisms and interactions with other genes related to both pharmacokinetics and 
pharmacodynamics.

\section{3. $C Y P 2 D 6$}

In vitro studies have also demonstrated a role of the CYP2D6 enzyme in the formation of EDDP from methadone, with a stereoselectivity towards $(R)$ methadone $[86,104]$. On the other hand, methadone has been described as an inhibitor of CYP2D6, and this should be taken into account in polypharmacy [105]. CYP2D6 displays strong genetic polymorphism; some are non-functional or have reduced function and others are duplicated, increasing the expression of the protein. Different allele combinations cause a range of phenotypes in terms of metabolism activity: two non-functional alleles lead to a poor metabolizer (PM) phenotype, at least one functional allele leads to an extensive metabolizer (EM) phenotype, and multiple copies of a functional allele lead to an ultra-rapid metabolizer (UM) phenotype [106]. A number of phenotypes have been associated with variations in methadone plasma concentrations: PM subjects had higher methadone plasma concentrations than did EM and UM subjects [92, 107]. These results have not been replicated [108].

Two studies have found some influence of CYP2D6 on methadone dose requirements. Fonseca et al. [93] described an effect of CYP2D6 phenotype status on response outcome, with UM subjects requiring higher doses of methadone. Levran et al. [94] observed that a non-coding SNP (rs3892097) was associated with daily methadone dose. Both studies were based on small sample sizes, evaluated more genes, and, although they controlled for multiple testing, could lead to a risk for false-positive results.

\section{4. $C Y P_{2} C_{19}$}

Several studies have evaluated the involvement of the CYP2C19 enzyme in methadone metabolism and its possible stereoselectivity. Although results have generally been controversial, a number of in vitro experiments indicated a minor involvement of CYP2C19 with stereoselectivity towards the $(R)$-enantiomer $[85,87,91]$. Crettol et al. $[25,92]$ did not demonstrate an association with methadone plasma concentrations, dose requirements, or methadone treatment outcome. Another study evaluated allelic combinations of $C Y P 450$ genetic variants (two from $C Y P 2 C 19$, four from $C Y P 2 B 6$, and five from $C Y P 3 A 4$ ) in 366 heroin-dependent patients receiving MMT for a possible influence on daily dose or illicit opioid use. The interaction analysis reported some influence of CYP2C19 on methadone dose, but data were not presented in the paper [96]. 
The same authors published a second paper evaluating an association between CYP2C19 metabolising phenotype (based on genotype at rs4244285 and rs4986893) and methadone doses and found that EM subjects consumed higher doses of methadone than intermediate metabolizers and PM (58.78 \pm 32.69 , $57.64 \pm 28.69$, and $40.45 \pm 22.17 \mathrm{mg} /$ day; $p=0.004$ and 0.001 , respectively) [109]. As with the previous genetic studies, the sample size was quite small and multiple tests were performed. Two different papers were published [96, 109], but the sample characteristics were the same for both and it is not clear whether one was a replication study.

\subsection{P-glycoprotein}

Methadone is a substrate of P-glycoprotein, which shows weak stereoselectivity towards the $(S)$-enantiomer [110]. The P-glycoprotein is encoded by the multidrug resistance $1(A B C B 1)$ gene (chromosome $7 \mathrm{p} 21)$. This gene is highly polymorphic, and numerous variants have been associated with drug response [111]. In vitro studies evaluating interactions between P-glycoprotein and methadone have shown that methadone is an inhibitor of the wild-type human protein [112] in a non-competitive way [113]. The same authors observed that different variants of P-glycoprotein presented less inhibition potency, explaining in part the disparities in the amount of methadone required for successful treatment when other substrates of P-glycoprotein are administered [113].

At a clinical level, the majority of studies focused on a non-synonymous SNP: rs 1045642 (C3435T). T allele homozygotes showed lower in vivo duodenal protein expression [114]. There is a considerable degree of agreement regarding the influence of $A B C B 1$ genotypes on methadone plasma concentrations [55, 92, $103,113,115,116,117]$, which is not usually related to a single SNP but to specific haplotypes.

One study described differences in $(R)$ - and $(S)$-methadone clearance depending on the polymorphisms at rs2032582 and on ethnicity [118]. However, there was no clear association with response to treatment $[94,119]$. One pilot study evaluating environmental and genetic factors involved in response to MMT found that, in a sample of 178 patients, the $A B C B 12677$ T allele was associated with both methadone plasma concentrations and MMT outcome (based on selfreport and urine controls) [102].

An interesting study by Barratt et al. [54] showed that interactions between polymorphisms in $A B C B 1$ and $O P R M 1$ genes could result in differences in 
methadone doses required. The authors observed that, among wild-type subjects at $\mathrm{A} 118 \mathrm{G} \mathrm{SNP}$, an $A B C B 1$ variant haplotype group required significantly lower doses of methadone than $A B C B 1$ wild-type subjects. On the other hand, among those with the most common $A B C B 1$ haplotype combination, the $\mathrm{A} 118 \mathrm{G}$ genotype was associated with higher methadone plasma concentrations [54].

A meta-analysis [103] evaluated studies investigating $A B C B 1$ and its influence on methadone dose, plasma concentrations, and treatment response and found no association between the $A B C B 1$ polymorphism and the trough $(R),(S)$ concentrations, methadone dose, or response.

As P-glycoprotein is an efflux transporter acting at the BBB, genetic variability at this level would affect concentrations at the central nervous system rather than plasma concentrations. In conclusion, genetic variability at the $A B C B I$ level may have a minor influence on methadone dose requirements in opioiddependent subjects, interacting with other factors (pharmacodynamics and pharmacokinetics). However, such variability can be managed at the clinical level by modifying the methadone dose.

\section{6. rs 17180299}

One study used GWAS to identify the pharmacokinetic determinants of methadone $(R)$ - and $(S)$-enantiomer concentrations. A significant SNP, rs 17180299 , was identified as accounting for $9.5 \%$ of the variation in plasma concentrations of the methadone $(R)$-enantiomer [120]. This SNP is located in an intergenic region, but there is a relationship between rs17180299 and heterochromatic histone $\mathrm{H} 3$ lysine 9 trimethylation (H3K9me3) in the primary T-regulatory cells from peripheral blood [121]. The authors suggested that rs17180299 could influence the regulation of plasma $(R)$-methadone through the epigenetic histone modification of $H 3 \mathrm{~K} 9 \mathrm{me} 3$. The same study identified 17 haplotypes in spondin 1 (SPON1), GSG1-like (GSG1L), and CYP450 genes associated with the plasma concentration of methadone $(S)$-enantiomer.

\section{Genetic Variability and Methadone-Related Adverse Events}

\subsection{Minor Adverse Events}

Methadone-related adverse events are similar to those of other opioid agonists and are generally mild and tolerable, the most common being constipation, 
sweating, and insomnia [122]. Both pharmacodynamic and pharmacokinetic genes have been studied with respect to the presence of adverse events in MMT (Table 3).

Table 3

Main studies assessing genetic variability and its influence in adverse events in methadone maintenance treatment

\begin{tabular}{|c|c|c|c|}
\hline Study & Sample characteristics & $\begin{array}{l}\text { Gene } \\
\text { (SNPs) }\end{array}$ & Results \\
\hline \multicolumn{4}{|c|}{ Minor adverse events } \\
\hline $\begin{array}{l}\text { Wang } \\
\text { et al. [59] }\end{array}$ & $\begin{array}{l}366 \text { Han Chinese MMT } \\
\text { patients }\end{array}$ & $\begin{array}{l}\text { OPRM1; } \\
\text { rs1074287; } \\
\text { rs6912029; } \\
\text { rs1799971; } \\
\text { rs12209447; } \\
\text { rs510769; } \\
\text { rs3798676; } \\
\text { rs553202; } \\
\text { rs499796; } \\
\text { rs7748401; } \\
\text { rs495491; } \\
\text { rs10457090; } \\
\text { rs589046; } \\
\text { rs3778152; } \\
\text { rs563649; } \\
\text { rs2075572 }\end{array}$ & $\begin{array}{l}\text { Changes in libido scores } \\
\text { (dominant model) and } \\
\text { insomnia scores } \\
\text { (recessive model) were } \\
\text { associated with } \\
\text { rs } 1074287 ; \text { rs6912029; } \\
\text { rs } 12209447 \text {; rs510769; } \\
\text { rs3798676; rs7748401; } \\
\text { rs495491; rs10457090; } \\
\text { rs589046; rs3778152; } \\
\text { rs563649; rs2075572, } \\
\text { after adjusting for age, } \\
\text { sex, and BMI }\end{array}$ \\
\hline $\begin{array}{l}\text { Wachman } \\
\text { et al. } \\
\text { [123] }\end{array}$ & $\begin{array}{l}86 \text { newborns and their } \\
\text { mothers }(98 \% \text { White, non- } \\
\text { Hispanic) }\end{array}$ & $\begin{array}{l}80 \text { SNPs in } \\
14 \text { candidate } \\
\text { genes: } \\
\text { OPRM1; } \\
\text { OPRD1; } \\
\text { OPRK1; } \\
\text { PENK; } \\
\text { POMC; } \\
\text { PDYN; } \\
\text { PNOC; } \\
\text { OPRL1; } \\
\text { COMT; } \\
\text { GAL; } \\
\text { BDNF; } \\
\text { SLC6A2; } \\
\text { SLC6A3; } \\
\text { SLC6A4 }\end{array}$ & $\begin{array}{l}\text { Carriers of the G allele } \\
\text { at } O P R M 1(\mathrm{rs} 1799971) \\
\text { were at lower risk of } \\
\text { experiencing neonatal } \\
\text { withdrawal syndrome } \\
\text { due to MMT in their } \\
\text { mothers }\end{array}$ \\
\hline \multirow[t]{2}{*}{$\begin{array}{l}\text { Zahari } \\
\text { et al. } \\
{[124]}\end{array}$} & 165 Malay males in MMT & $\begin{array}{l}O P R M 1 \\
\text { rs1799971; } \\
\text { rs2075572 }\end{array}$ & $\begin{array}{l}\text { The AC/AG diplotype } \\
\text { for the A118G and } \\
\text { IVS2 + G691C } \\
\text { polymorphisms is } \\
\text { associated with better } \\
\text { sleep quality }\end{array}$ \\
\hline & & & Six SNPs from \\
\hline
\end{tabular}




\begin{tabular}{|c|c|c|c|}
\hline $\begin{array}{l}\quad \text { Wang } \\
\text { et al. } \\
\text { [125] }\end{array}$ & $\begin{array}{l}366 \text { Taiwanese MMT } \\
\text { patients }\end{array}$ & $\begin{array}{l}\text { OPRK1 } 17 \\
\text { SNPs }\end{array}$ & $\begin{array}{l}\text { rs } 7843965 \text { to rs } 1051660 \\
\text { (intron } 2 \text { to exon 2) were } \\
\text { significantly associated } \\
\text { with body weight. A } \\
\text { haplotype of four SNPs, } \\
\text { rs7832417-rs16918853- } \\
\text { rs702764-rs7817710 } \\
\text { (exon } 4 \text { to intron 3), was } \\
\text { associated with bone or } \\
\text { joint aches and with the } \\
\text { amount of alcohol use. } \\
\text { The haplotype } \\
\text { rs10958350-rs7016778- } \\
\text { rs12675595 was } \\
\text { associated with } \\
\text { gooseflesh skin, } \\
\text { yawning, and } \\
\text { restlessness withdrawal } \\
\text { symptoms }\end{array}$ \\
\hline $\begin{array}{l}\text { Chen } \\
\text { et al. } \\
{[126]}\end{array}$ & $\begin{array}{l}366 \text { Han Chinese MMT } \\
\text { patients }\end{array}$ & $\begin{array}{l}\text { CYP3A4 } \\
\text { (rs4646440 } \\
\text { and } \\
\text { rs224248) }\end{array}$ & $\begin{array}{l}\text { The SNPs were } \\
\text { associated with the } \\
\text { severity of withdrawal } \\
\text { symptoms and } \\
\text { methadone adverse } \\
\text { effects }\end{array}$ \\
\hline $\begin{array}{l}\text { Zahari } \\
\text { et al. } \\
\text { [128] }\end{array}$ & $\begin{array}{l}148 \text { Malay male MMT } \\
\text { patients }\end{array}$ & $\begin{array}{l}\text { CYP2B6 (*6 } \\
\text { allele) } \\
\text { rs3745274 }\end{array}$ & $\begin{array}{l}\text { The } C Y P 2 B 6^{*} 6 \text { allele } \\
\text { was associated with a } \\
\text { lower pain threshold and } \\
\text { lower pain tolerance }\end{array}$ \\
\hline $\begin{array}{l}\text { Tian et } \\
\text { al. }[127]\end{array}$ & $\begin{array}{l}366 \text { MMT patients in } \\
\text { Taiwan }\end{array}$ & $\begin{array}{l}U G T 2 B 7 ; \\
\text { rs6600879; } \\
\text { rs6600880; } \\
\text { rs4554144; } \\
\text { rs11940316; } \\
\text { rs7438135; } \\
\text { rs7662029; } \\
\text { rs7668258; } \\
\text { rs7439366; } \\
\text { rs4292394; } \\
\text { rs6600893 }\end{array}$ & $\begin{array}{l}\text { Significant associations } \\
\text { with severity of } \\
\text { withdrawal symptoms, } \\
\text { pupil size and tremor }\end{array}$ \\
\hline
\end{tabular}

Serious adverse events

\begin{tabular}{|c|c|c|c|}
\hline $\begin{array}{l}\text { Wong } \\
\text { et al. } \\
{[130]}\end{array}$ & $\begin{array}{l}21 \text { methadone-related } \\
\text { deaths }\end{array}$ & $\begin{array}{l}\text { CYP 2D6 } \\
\text { alleles; } \\
\text { rs35742686 } \\
(C Y P 2 D 6 \\
* 3), \\
\text { rs3892097 } \\
(C Y P 2 D 6 \\
* 4) \text {, whole } \\
\text { gene } \\
\text { deletion } \\
(C Y P 2 D 6 \\
* 5)\end{array}$ & $\begin{array}{l}\text { The prevalence of poor } \\
\text { metabolizers was higher } \\
\text { but not significantly } \\
\text { different from that of a } \\
\text { control group }\end{array}$ \\
\hline & & & CYP2B6: In the group of \\
\hline
\end{tabular}




\section{Bunten}

et al.

[131,

132]
40 individuals with deaths associated with MMT
CYP $2 B 6 * 6$ (rs3745274); OPRM1 (rs1799971)
136 methadone accidental overdoses: 133 involved

RichardsWaugh et al. [133] methadone-only overdoses; 95 combined methadone/benzodiazepine overdoses
CYP $3 A 4$ rs2246709; rs 3735451 ; rs4646437; rs2242480; rs4987161; rs4986910; rs2740574

slow metabolizers, the post-mortem plasma concentrations of methadone were higher than other genotypes.

OPRM 1: Carriers of the 118GA genotype presented higher benzodiazepine plasma concentrations in the methadone-related deaths, but not in the morphine-related deaths

Two SNPs: rs2242480 and rs 2740574

demonstrated an apparent enrichment within the methadoneonly overdose fatalities compared with the control group and the general population

The frequencies of SNPs rs3745274 (*9) and rs8192719 (C21563T) were enhanced in the methadone-only group.

CYP2B6; rs2279344; rs3211371; rs3745274; rs4803419; rs8192709; rs8192719; rs12721655; rs35979566

Higher blood methadone concentrations were observed in individuals who were genotyped homozygous for SNP rs3211371 (*5) $(1.67 \pm 0.85)$ as compared with either the heterozygote $(0.52 \pm 0.08)$ or homozygous ancestral genotype $(0.59 \pm 0.05)$, $p<0.05$

The A118G polymorphism was not associated with lifetime

OPRM1; rs1799971 suicide attempts. Suicide risk was associated with major depression diagnosis

Each copy of a Lys KCNH2: allele at codon 897 of rs1805123; KCNH2, the gene that KCNE1: rs1805127; potassium voltage-gated KCNE1: rs2236609 channel hERG, was associated with a15.4 ms longer Qtc 


\begin{tabular}{|c|c|c|c|}
\hline $\begin{array}{l}\text { Eap et } \\
\text { al. [144] }\end{array}$ & $\begin{array}{l}179 \text { Caucasian MMT } \\
\text { patients. Methadone dose } \\
145 \pm 83 \mathrm{mg} / \text { day }\end{array}$ & $\begin{array}{l}\text { CYP2B6 } \\
(* 6) \\
\text { rs3745274 }\end{array}$ & $\begin{array}{l}\text { The mean QTc was } \\
\text { higher in CYP2B6 slow } \\
\text { metabolizers } \\
(439 \pm 25 \mathrm{~ms}) \text { than in } \\
\text { extensive metabolizers } \\
(421 \pm 25 \mathrm{~ms} ; p=0.017)\end{array}$ \\
\hline $\begin{array}{l}\text { Wang } \\
\text { et al. } \\
\text { [109] }\end{array}$ & $\begin{array}{l}366 \text { MMT patients in } \\
\text { Taiwan }\end{array}$ & $\begin{array}{l}\text { CYP2C19; } \\
\text { rs4986893; } \\
\text { rs4244285 }\end{array}$ & $\begin{array}{l}\text { Methadone daily doses } \\
\text { of both the extensive } \\
\text { metabolizers } \\
(58.78 \pm 32.69 \mathrm{mg} / \mathrm{day} ; \\
p=0.004) \text { and } \\
\text { intermediate } \\
\text { metabolizers } \\
(57.64 \pm 28.69 \mathrm{mg} / \text { day; } \\
p=0.001) \text { were } \\
\text { significantly higher than } \\
\text { that of the poor } \\
\text { metabolizers } \\
(40.45 \pm 22.17 \mathrm{mg} / \text { day }) \\
\text { Poor metabolizers had } \\
\text { higher plasma } \\
\text { concentrations of both } \\
\text { dose-corrected plasma } \\
\text { concentrations of }(R)- \\
\text { methadone }(p=0.002) \\
\text { and }(R)-\text { EDDP } \\
(p=0.03) \text { than extensive } \\
\text { metabolizers }\end{array}$ \\
\hline $\begin{array}{l}\text { Carlquist } \\
\text { et al. } \\
\text { [146] }\end{array}$ & $\begin{array}{l}25 \text { MMT patients: } \\
\text { Caucasian }(74 \%) \text {, } \\
\text { Hispanic }(19 \%) \text {, African } \\
\text { American }(3 \%) \text {, Native } \\
\text { American }(3 \%)\end{array}$ & СУР2C19 & $\begin{array}{l}\text { Carriers of the } \\
C Y P 2 C 19^{*} 2 \text { variant } \\
\text { presented higher } \\
\text { concentrations of plasma } \\
\text { EDDP, }(S) \text {-EDDP, and } \\
(R) \text {-EDDP }(p=0.004) \text {. } \\
\text { The methadone dose and } \\
\text { the plasma EDDP } \\
\text { concentration corrected } \\
\text { for dose were both } \\
\text { significantly associated } \\
\text { with QTc }\end{array}$ \\
\hline
\end{tabular}

$B M I$ body mass index, EDDP 2-ethylidene-1,5-dimethyl-3,3-diphenylpyrrolidine, $M M T$ methadone maintenance treatment, $S N P$ single nucleotide polymorphism

\subsubsection{OPRM1}

Wang et al. [59] reported that 11 SNPs at OPRM1 were associated with insomnia and changes in libido. In neonates, carriers of the $G$ allele in the A118G SNP were at lower risk of experiencing neonatal withdrawal syndrome due to their mother's MMT treatment [123]. Zahari et al. [124] studied sleep quality and $O P R M 1$ genetic variability and found an association between a diplotype of two SNPs and sleep quality among males receiving methadone 
treatment.

\subsubsection{Kappa Opioid Receptor $1(O P R K 1)$}

The kappa opioid receptor has also been associated with minor MMT-related adverse events. Methadone binds to the kappa opioid receptor but with low affinity. From a selection of 17 SNPs in the OPRK1 gene, six were significantly associated with body weight, a low frequency haplotype $(6.1 \%)$ of four SNPsrs7832417-rs16918853-rs702764-rs7817710 (exon 4 to intron 3) -was associated with bone or joint aches, and the haplotype rs10958350-rs7016778rs 12675595 was associated with gooseflesh skin, yawning, and restlessness withdrawal symptoms [125]. This same sample of subjects receiving MMT has been used in other studies [59, 109, 126, 127] also analysing multiple SNPs and genes, which signifies that the results have a high risk of a type I error.

\subsection{3. $\mathrm{CYP}_{3} \mathrm{~A}_{4}$}

In terms of pharmacokinetics, an association between CYP3A4 genotype and withdrawal symptoms and methadone-related adverse events was observed in patients receiving MMT [126]. This study evaluated withdrawal syndrome in 366 Han Chinese with the Clinical Opioid Withdrawal Scale (COWS) and found that two SNPs (rs4646440 and rs2242480) showed an association with total scores of the scale. Four SNPs (rs3735451, rs4646440, rs2242480, rs4646437, and rs2246709) were also associated with methadone-related adverse events, mainly sedation.

\subsection{4. $C Y P_{2} B 6$}

Hyperalgesia is frequently reported by formerly opioid-dependent patients. The CYP2B6 gene has been studied to ascertain its possible influence on pain sensitivity in patients receiving MMT. In a set of 148 such patients who were assessed using the cold presser test, the $C Y P 2 B 6^{*} 6$ allele carriers had a shorter cold pain threshold and pain tolerance time than non-carriers [128].

\subsubsection{UDP Glucuronosyltransferase Family 2 Member B7 (UGT2B7)}

Tian et al. [127] also evaluated the genetic basis of withdrawal syndrome severity in patients receiving MMT, focussing on polymorphisms at the $U G T 2 B 7$ gene. In urine-positive subjects, ten SNPs were significantly associated with withdrawal symptoms and tremor. Other studies have shown 
that methadone is an inhibitor of this gene, presenting cross-tolerance with morphine, although methadone is not a substrate of this gene [129].

\subsection{Severe Adverse Events}

Two major adverse events are related to methadone: respiratory depression and ventricular arrhythmia [122].

\subsubsection{Overdose Risk}

Studying the pharmacokinetics of methadone could help describe the different risks for overdose. Wong et al. [130] evaluated a number of CYP2D6 allelesrs35742686 (CYP2D6*3), rs3892097 (CYP2D6*4), and whole gene deletion (CYP2D6 *5 variant), associated with poor drug metabolism - in 21 deaths involving methadone. The prevalence of PMs was higher but not significantly different from that in the control group, but the small sample size could have decreased statistical power. CYP2B6 encoding gene was also assessed in the risk of overdose deaths $[131,132]$. The authors described an association with $C Y P 2 B 6^{*} 6 / * 6$ genotype (PM phenotype): carriers had higher post-mortem plasma concentrations of methadone than did other genotypes. In addition, the same study also detected an association between the A118G SNP at OPRM1, and heterozygotes presented higher benzodiazepine plasma concentrations than 118 AA carriers $(0.69 \pm 0.363$ vs. $1.66 \pm 0.749 ; p=0.004)$ in methadone-related but not in morphine-related deaths, indicating a pharmacodynamicpharmacokinetic interaction.

Two SNPs, rs2242480 and rs2740574, of the main enzyme involved in methadone metabolism, CYP3A4, were associated with accidental methadone overdoses; they were found more frequently in those deaths compared with the control group, indicating a possible contribution to the methadone PM phenotype [133]. Finally, a recent study reported an association between the CYP2B6 SNPs rs3745274 and rs35979566 and methadone overdoses [134].

In many cases of overdose, it is difficult to distinguish between an accidental death and a suicide attempt. In a study examining the risk of intentional overdose in patients stabilized on MMT, the authors found an association with suicide attempts and a diagnosis of major depression but not with differences in the A118G SNP [135].

\subsubsection{QTc Prolongation}


The prolongation of the QTc interval on electrocardiograms, and cardiac arrhythmias such as Torsades de Pointes, has been extensively studied [136, 137, 138]. Patients receiving methadone treatment with QTc prolongation usually present with other risk factors [139], such as cocaine and alcohol use, cardiotoxic drugs [140], and higher doses of methadone [141]. The mechanisms of QTc prolongation have been related to the inhibition of the cardiac potassium channel hERG induced by methadone, with $(S)$-methadone showing more potent inhibition than $(R)$-methadone [142]. Genetics at this level have also been studied to detect patients susceptible to developing this severe adverse event. One polymorphism at the potassium voltage-gated channel subfamily $\mathrm{H}$ member 2 (KCNH2, rs 1805123 number of 897Lys) encoding for the potassium channel has been associated with longer QTc intervals in patients receiving methadone treatment [143].

Eap et al. [144] found differences in the QTc interval depending on the metabolizer status at $C Y P 2 B 6$ : PM of $C Y P 2 B 6$ presented longer QTc intervals than EM. As cardiac adverse events have been related to the $(S)$-enantiomer, the authors compared the administration of $(R, S)$ - versus $(R)$-methadone and described a reduction in the QTc interval by substituting $(R, S)$-methadone for the active $(R)$-enantiomer [145]. Moreover, two studies reported that a polymorphism at the CYP2C19 gene (rs4244285) was associated with QTc interval, methadone doses, $(R)$-methadone/methadone plasma concentration ratio, and EDDP (main methadone metabolite) concentrations $[109,146]$. An interesting study [142] evaluated the different contributions of genetic and nongenetic factors to the effects of methadone on QTc changes. Polymorphisms at $C Y P 2 B 6, A B C B 1$ influenced the clearance of $(S)$-methadone, as well as levels of $\alpha-1$ acid glycoprotein (AAG), a protein that also binds methadone in plasma [147]. Patients with doses of methadone $>240 \mathrm{mg} /$ day and a low clearance profile had a higher risk of prolonged QTc ( 8 vs. 18\%). It is also important to take into account that AAG binds plasma methadone, showing differences among the variants of the protein.

\section{Conclusions}

This review aimed to present a thorough summary of published studies regarding genetic influences on outcomes in MMT. The results presented in this paper show both considerable heterogeneity and contrasting results. The latter could be due to differences in study methods: small sample sizes, lack of control for multiple testing, and the risk of a stratification effect due to varying ethnic 
origins. Moreover, factors associated with the characteristics of the subjects and methadone programmes (different definitions of "good response," the presence of and/or therapeutic approach regarding medical and psychiatric comorbidities, and services other than methadone) may have played a role. Accurate phenotypes are imperative in pharmacogenomic studies.

Despite the limitations, we can draw some conclusions from the studies reviewed. OPRM1 SNP rs1799971 (A118G) alone is not associated with response to methadone treatment but may have an influence via interactions with other genes (mainly involved in pharmacokinetics). In the genes coding for enzymes involved in methadone metabolism, studies have found influences from $C Y P 2 B 6, C Y P 2 D 6$, and $C Y P 2 C 19$ in methadone dose requirements. It is not possible to confirm a positive or negative association in the rest of the studied genes because of a lack of replication analysis. Methadone-related adverse events (such as sleep disturbance and sexual dysfunction) have been associated with different SNPs at the OPRM1 gene. Finally, genotypes involving slow methadone metabolism have been involved with a higher risk of QTc enlargement.

Outcomes of MMT are the result of a combination of environmental, druginduced, and genetic factors. They could be directly related to pharmacodynamic and/or pharmacokinetic factors. The influence of genetic variability in the coding genes involved in the pharmacokinetics of methadone metabolism and transport can be clinically managed, usually by increasing or decreasing methadone doses or splitting the daily dose. A better understanding of pharmacodynamic factors could help to select the best opioid for treatment; for example, the kappa antagonistic effect of buprenorphine would be beneficial in cases of comorbidity with depression [148].

The high variability in methadone metabolism and plasma concentrations and its relationship with serious adverse events, such as QTc prolongation, makes the implementation of regular electrocardiogram monitoring in patients receiving methadone treatment mandatory.

Although pharmacogenetic studies seemed promising years ago, they have not met expectations regarding their application to MMT. When considering therapeutic options for the treatment of opioid addiction, clinicians need information regarding genetic conditioning on methadone metabolism, enantiomer clearance, and the presence of genotypes associated with the risk of 
adverse effects. They must also consider the other phenotypic characteristics of their patients.

Compliance with Ethical Standards

Funding This study was funded in part by Instituto de Salud Carlos III, Red de Trastornos Adictivos UE-FEDER 2012 (RD12/0028/0009); Instituto de Salud Carlos III-FEDER-Red de Trastornos Adictivos UE-FEDER 2016 RD16/0017/0010; and AGAUR-Suport Grups de Recerca (2014 SGR790).

Conflict of interest Dr. Francina Fonseca and Dr. Marta Torrens have no conflicts of interest.

\section{Electronic supplementary material}

Below is the link to the electronic supplementary material.

Supplementary material 1 (DOCX $25 \mathrm{~kb}$ )

\section{References}

1. United Nations Office on Drugs and Crime. World Drug Report 2016. Vienna: (United Nations publication, Sales No. E.16.XI.7); 2016.

2. Koob GF, Volkow ND. Neurobiology of addiction: a neurocircuitry analysis. Lancet Psychiatry. 2016;3:760-73.

3. Sellman D. The 10 most important things known about addiction. Addiction. 2010;105:6-13.

4. Kreek MJ, Levran O, Reed B, Schlussman SD, Zhou Y, Butelman ER. Opiate addiction and cocaine addiction: Underlying molecular neurobiology and genetics. J Clin Invest. 2012;122:3387-935.

5. Veilleux JC, Colvin PJ, Anderson J, York C, Heinz AJ. A review of opioid dependence treatment: pharmacological and psychosocial interventions to treat opioid addiction. Clin Psychol Rev. 2010;30:155-66. 
6. Fiellin DA, Friedland GH, Gourevitch MN. Opioid dependence: rationale for and efficacy of existing and new treatments. Clin Infect Dis. 2006;43(Suppl 4):S173-7.

7. Mattick RP, Breen C, Kimber J, Davoli M. Methadone maintenance therapy versus no opioid replacement therapy for opioid dependence. Cochrane Database Syst Rev. 2009;(3):CD002209.

8. Nielsen S, Larance B, Degenhardt L, Gowing L, Kehler C, Lintzeris N. Opioid agonist treatment for pharmaceutical opioid dependent people. Cochrane Database Syst Rev. 2016; (5):CD011117. AQ6

9. Mattick RP, Breen C, Kimber J, Davoli M, Rp M, Breen C, et al. Buprenorphine maintenance versus placebo or methadone maintenance for opioid dependence. Cochrane Database Syst Rev. 2014; 2:CD002207.

10. Amato L, Davoli M, Perucci CA, Ferri M, Faggiano F, Mattick RP. An overview of systematic reviews of the effectiveness of opiate maintenance therapies: available evidence to inform clinical practice and research. J Subst Abuse Treat. 2005;28:321-9.

11. Connock M, Juarez-Garcia A, Jowett S, Frew E, Liu Z, Taylor RJ, et al. Methadone and buprenorphine for the management of opioid dependence: a systematic review and economic evaluation. Health Technol. 2007;11:1-171.

12. Torrens M, Fonseca F, Castillo C, Domingo-Salvany A. Methadone maintenance treatment in Spain: the success of a harm reduction approach. Bull World Health Organ. 2013;91:136-41.

13. Dolan KA, Shearer J, White B, Zhou J, Kaldor J, Wodak AD. Four-year follow-up of imprisoned male heroin users and methadone treatment: mortality, re-incarceration and hepatitis $\mathrm{C}$ infection. Addiction. 2005;100:820-8.

14. Brugal MT, Domingo-Salvany A, Puig R, Barrio G, Garcia de Olalla P, de la Fuente L. Evaluating the impact of methadone maintenance programmes on mortality due to overdose and aids in a cohort of heroin 
users in Spain. Addiction. 2005;100:981-9.

15. Zhou K, Wang D, Li H, Wei X, Yin J, Liang P, et al. Bidirectional relationships between retention and health-related quality of life in Chinese mainland patients receiving methadone maintenance treatment. PLoS One. 2017;12:e0179009 (Le Foll B, editor.).

16. Eap CB, Buclin T, Baumann P. Interindividual variability of the clinical pharmacokinetics of methadone: implications for the treatment of opioid dependence. Clin Pharmacokinet. 2002;41:1153-93.

17. Silverman DAN, Nettleton RT, Spencer KB, Wallisch M, Olsen GD. SMethadone augments R-methadone induced respiratory depression in the neonatal guinea pig. Respir Physiol Neurobiol. 2009;169:252-61.

18. Eap CB, Finkbeiner T, Gastpar M, Scherbaum N, Powell K, Baumann P. Replacement of (R)-methadone by a double dose of (R, S)-methadone in addicts: interindividual variability of the $(\mathrm{R}) /(\mathrm{S})$ ratios and evidence of adaptive changes in methadone pharmacokinetics. Eur J Clin Pharmacol. 1996;50:385-9.

19. Beck O, Boreus LO, Lafolie P, Jacobsson G. Chiral analysis of methadone in plasma by high-performance liquid chromatography. $\mathrm{J}$ Chromatogr. 1991;570:198-202.

20. Foster DJ, Somogyi AA, White JM, Bochner F. Population pharmacokinetics of (R)-, (S)- and rac-methadone in methadone maintenance patients. Br J Clin Pharmacol. 2004;57:742-55.

21. Mouly S, Bloch V, Peoc'h K, Houze P, Labat L, Ksouda K, et al. Methadone dose in heroin-dependent patients: role of clinical factors, comedications, genetic polymorphisms and enzyme activity. Br J Clin Pharmacol. 2015;79:967-77.

22. Garrido MJ, Aguirre C, Trocóniz IF, Marot M, Valle M, Zamacona MK, et al. Alpha 1-acid glycoprotein (AAG) and serum protein binding of methadone in heroin addicts with abstinence syndrome. Int J Clin Pharmacol Ther. 2000;38:35-40. 
23. Wolff K, Rostami-Hodjegan A, Shires S, Hay AW, Feely M, Calvert R, et al. The pharmacokinetics of methadone in healthy subjects and opiate users. Br J Clin Pharmacol. 1997;44:325-34.

24. Bell J, Seres V, Bowron P, Lewis J, Batey R. The use of serum methadone levels in patients receiving methadone maintenance. Clin Pharmacol Ther. 1988;43:623-9.

25. Crettol S, Deglon JJ, Besson J, Croquette-Krokkar M, Gothuey I, Hammig R, et al. Methadone enantiomer plasma levels, CYP2B6, CYP2C19, and CYP2C9 genotypes, and response to treatment. Clin Pharmacol Ther. 2005;78:593-604.

26. Torrens M, Castillo C, San L, del Moral E, Gonzalez ML, de la Torre R. Plasma methadone concentrations as an indicator of opioid withdrawal symptoms and heroin use in a methadone maintenance program. Drug Alcohol Depend. 1998;52:193-200.

27. Borg L, Ho A, Peters JE, Kreek MJ. Availability of reliable serum methadone determination for management of symptomatic patients. J Addict Dis. 1995; 14:83-96.

28. Loimer N, Schmid R, Grunberger J, Jagsch R, Linzmayer L, Presslich O. Psychophysiological reactions in methadone maintenance patients do not correlate with methadone plasma levels. Psychopharmacology. 1991;103:538-40.

29. Dyer KR, Foster DJ, White JM, Somogyi AA, Menelaou A, Bochner F. Steady-state pharmacokinetics and pharmacodynamics in methadone maintenance patients: comparison of those who do and do not experience withdrawal and concentration-effect relationships. Clin Pharmacol Ther. 1999;65:685-94.

30. Eap CB, Bourquin M, Martin J, Spagnoli J, Livoti S, Powell K, et al. Plasma concentrations of the enantiomers of methadone and therapeutic response in methadone maintenance treatment. Drug Alcohol Depend. 2000;61:47-54.

31. Valentová J, Horáková R, Pechová I, Okruhlica L, Devínsky F. 
Stereoselective determination of methadone and its main metabolite in serum and urine from methadone maintenance patients. Neuroendocrinol Lett. 2006;27(Suppl 2):130-3.

32. Hiltunen AJ, Beck O, Hjemdahl P, Liljeberg P, Almstrom U, Brodin K, et al. Rated well-being in relation to plasma concentrations of 1- and dmethadone in satisfied and dissatisfied patients on methadone maintenance treatment. Psychopharmacology. 1999;143:385-93.

33. Meini M, Moncini M, Daini L, Giarratana T, Scaramelli D, Chericoni S, et al. Relationship between plasma concentrations of the 1-enantiomer of methadone and response to methadone maintenance treatment. Eur J Pharmacol. 2015;760:1-6.

34. Bell J, Burrell T, Indig D, Gilmour S. Cycling in and out of treatment; participation in methadone treatment in NSW, 1990-2002. Drug Alcohol Depend. 2006;81:55-61.

35. Faggiano F, Vigna-Taglianti F, Versino E, Lemma P. Methadone maintenance at different dosages for opioid dependence. Cochrane Database Syst Rev. 2003; (3):CD002208 (Faggiano F, editor).

36. Villafranca SW, McKellar JD, Trafton JA, Humphreys K. Predictors of retention in methadone programs: a signal detection analysis. Drug Alcohol Depend. 2006;83:218-24.

37. Trafton JA, Tracy SW, Oliva EM, Humphreys K, et al. Different components of opioid-substitution treatment predict outcomes of patients with and without a parent with substance-use problems. J Stud Alcohol Drugs. 2007;68:165-72.

38. Li Y, Kantelip JP, Gerritsen-van Schieveen P, Davani S. Interindividual variability of methadone response: impact of genetic polymorphism. Mol Diagn Ther. 2008;12:109-24.

39. Somogyi AA, Barratt DT, Ali RL, Coller JK. Pharmacogenomics of methadone maintenance treatment. Pharmacogenomics. 2014;15:1007-27. 
40. Attia J, Ioannidis JPA, Thakkinstian A, McEvoy M, Scott RJ, Minelli C, et al. How to use an article about genetic association: B: are the results of the study valid? JAMA. 2009;301:191-7.

41. Wang JB, Johnson PS, Persico AM, Hawkins AL, Griffin CA, Uhl GR. Human mu opiate receptor. cDNA and genomic clones, pharmacologic characterization and chromosomal assignment. FEBS Lett. 1994;338:21722 .

42. Bond C, LaForge KS, Tian M, Melia D, Zhang S, Borg L, et al. Singlenucleotide polymorphism in the human mu opioid receptor gene alters betaendorphin binding and activity: possible implications for opiate addiction. Proc Natl Acad Sci USA. 1998;95:9608-13.

43. Zhang Y, Wang D, Johnson AD, Papp AC, Sadee W. Allelic expression imbalance of human mu opioid receptor (OPRM1) caused by variant A118G. J Biol Chem. 2005;280:32618-24.

44. Oertel BG, Kettner M, Scholich K, Renne C, Roskam B, Geisslinger G, et al. A common human micro-opioid receptor genetic variant diminishes the receptor signaling efficacy in brain regions processing the sensory information of pain. J Biol Chem. 2009;284:6530-5.

45. Kroslak T, Laforge KS, Gianotti RJ, Ho A, Nielsen DA, Kreek MJ. The single nucleotide polymorphism A118G alters functional properties of the human mu opioid receptor. J Neurochem. 2007;103:77-87.

46. Hernandez-Avila CA, Wand G, Luo X, Gelernter J, Kranzler HR. Association between the cortisol response to opioid blockade and the Asn40Asp polymorphism at the mu-opioid receptor locus (OPRM1). Am J Med Genet B Neuropsychiatr Genet. 2003;118B:60-5.

47. Schwantes-An TH, Zhang J, Chen LS, Hartz SM, Culverhouse RC, Chen X, et al. Association of the OPRM1 variant rs1799971 (A118G) with nonspecific liability to substance dependence in a collaborative de novo metaanalysis of european-ancestry cohorts. Behav Genet. 2016;46:151-69.

48. Wu WD, Wang Y, Fang YM, Zhou HY. Polymorphism of the microopioid receptor gene (OPRM1 118A $>$ G) affects fentanyl-induced analgesia 
during anesthesia and recovery. Mol Diagn Ther. 2009;13:331-7.

49. De Capraris A, Cinnella G, Marolla A, Salatto P, Da Lima S, Vetuschi P, et al. Micro opioid receptor A118G polymorphism and post-operative pain: opioids' effects on heterozigous patients. Int J Immunopathol Pharmacol. 2011;24:993-1004.

50. Mura E, Govoni S, Racchi M, Carossa V, Nadia Ranzani G, Allegri M, et al. Consequences of the $118 \mathrm{~A}>\mathrm{G}$ polymorphism in the OPRMI gene: translation from bench to bedside? J Pain Res. 2013;6:331-53.

51. Smith AH, Jensen KP, Li J, Nunez Y, Farrer LA, Hakonarson H, et al. Genome-wide association study of therapeutic opioid dosing identifies a novel locus upstream of OPRM1. Mol Psychiatry. 2017;22:346-52.

52. Hwang IC, Park JY, Myung SK, Ahn HY, Fukuda K, Liao Q. OPRM1 A118G gene variant and postoperative opioid requirement: a systematic review and meta-analysis. Anesthesiology. 2014;121:825-34.

53. Lotsch J, Skarke C, Wieting J, Oertel BG, Schmidt H, Brockmoller J, et al. Modulation of the central nervous effects of levomethadone by genetic polymorphisms potentially affecting its metabolism, distribution, and drug action. Clin Pharmacol Ther. 2006;79:72-89.

54. Barratt DT, Coller JK, Hallinan R, Byrne A, White JM, Foster DJR, et al. ABCB1 haplotype and OPRM1 118A $>\mathrm{G}$ genotype interaction in methadone maintenance treatment pharmacogenetics. Pharmacogenomics. 2012;5:53-62.

55. Hung CC, Chiou MH, Huang BH, Hsieh YW, Hsieh TJ, Huang CL, et al. Impact of genetic polymorphisms in ABCB1, CYP2B6, OPRM1, ANKK1 and DRD2 genes on methadone therapy in Han Chinese patients. Pharmacogenomics. 2011;12:1525-33.

56. Crettol S, Besson J, Croquette-Krokar M, Hammig R, Gothuey I, Monnat M, et al. Association of dopamine and opioid receptor genetic polymorphisms with response to methadone maintenance treatment. Prog Neuropsychopharmacol. 2008;32:1722-7. 
57. Nielsen D, Ji F, Yuferov V, Ho A, Chen A, Levran O, et al. Genotype patterns that contribute to increased risk for or protection from developing heroin addiction. Mol Psychiatry. 2008;13:417-28.

58. Fonseca F, Gratacòs M, Escaramís G, De Cid R, Martín-Santos R, Fernández-Espejo E, et al. Response to methadone maintenance treatment is associated with the MYOCD and GRM6 genes. Mol Diagn Ther. 2010;14:171-8.

59. Wang SC, Tsou HH, Chen CH, Chen YT, Ho IK, Hsiao CF, et al. Genetic polymorphisms in the opioid receptor mul gene are associated with changes in libido and insomnia in methadone maintenance patients. Eur Neuropsychopharmacol. 2012;22:695-703.

60. Levran O, Peles E, Randesi M, Shu X, Ott J, Shen P-H, et al. Association of genetic variation in pharmacodynamic factors with methadone dose required for effective treatment of opioid addiction. Pharmacogenomics. 2013;14:755-68.

61. Crist RC, Doyle GA, Nelson EC, Degenhardt L, Martin NG, Montgomery GW, et al. A polymorphism in the OPRM1 3'-untranslated region is associated with methadone efficacy in treating opioid dependence. Pharmacogenomics J. 2016. https://doi.org/10.1038/tpj.2016.89 (epub ahead of print).

62. Hastie BA, Riley JL, Kaplan L, Herrera DG, Campbell CM, Virtusio K, et al. Ethnicity interacts with the OPRM1 gene in experimental pain sensitivity. Pain. 2012;153:1610-9.

63. Lutz P-E, Kieffer BL. Opioid receptors: distinct roles in mood disorders. Trends Neurosci. 2013;36:195-206.

64. Lutz P-E, Kieffer BL. The multiple facets of opioid receptor function: implications for addiction. Curr Opin Neurobiol. 2013;23:473-9.

65. LaForge KS, Yuferov V, Kreek MJ. Opioid receptor and peptide gene polymorphisms: potential implications for addictions. Eur J Pharmacol. 2000;410:249-68. 
66. Crist RC, Clarke TK, Ang A, Ambrose-Lanci LM, Lohoff FW, Saxon AJ, et al. An intronic variant in OPRD1 predicts treatment outcome for opioid dependence in African-Americans. Neuropsychopharmacology. 2013;38:2003-10.

67. Patriquin MA, Bauer IE, Soares JC, Graham DP, Nielsen DA. Addiction pharmacogenetics: a systematic review of the genetic variation of the dopaminergic system. Psychiatr Genet. 2015;25:181-93.

68. Doehring A, Hentig N, Graff J, Salamat S, Schmidt M, Geisslinger G, et al. Genetic variants altering dopamine D2 receptor expression or function modulate the risk of opiate addiction and the dosage requirements of methadone substitution. Pharmacogenet Genomics. 2009;19:407-14.

69. Bawor M, Dennis BB, Tan C, Pare G, Varenbut M, Daiter J, et al. Contribution of BDNF and DRD2 genetic polymorphisms to continued opioid use in patients receiving methadone treatment for opioid use disorder: an observational study. Addict Sci Clin Pract. 2015;10:19.

70. Huang M, Chiang T, Lo P, Huang C. Relationship among methadone dose, polymorphisms of dopamine $\mathrm{D} 2$ receptor and tri-dimensional personality questionnaire in heroin-addicted patients. Behav Brain Funct. 2016;12:24.

71. Lawford BR, Young RM, Noble EP, Sargent J, Rowell J, Shadforth S, et al. The $\mathrm{D}(2)$ dopamine receptor $\mathrm{A}(1)$ allele and opioid dependence: association with heroin use and response to methadone treatment. Am J Med Genet. 2000;96:592-8.

72. Barratt DT, Coller JK, Somogyi AA. Association between the DRD2 A1 allele and response to methadone and buprenorphine maintenance treatments. Am J Med Genet B Neuropsychiatr Genet. 2006;141B:323-31.

73. Porter-Stransky KA, Weinshenker D. Arresting the development of addiction: the role of $\beta$-arrestin 2 in drug abuse. J Pharmacol Exp Ther. 2017;361:341-8.

74. Ambrose-Lanci LM, Vaswani M, Clarke T-K, Zeng A, Lohoff FW, Ferraro TN, et al. Association study of the $\beta$-arrestin 2 gene (ARRB2) with 
opioid and cocaine dependence in a European American population. Psychiatr Genet. 2012;22:141-5.

75. Sun D, Ma JZ, Payne TJ, Li MD. Beta-arrestins 1 and 2 are associated with nicotine dependence in European American smokers. Mol Psychiatry. 2008;13:398-406.

76. Oneda B, Crettol S, Bochud M, Besson J, Croquette-Krokar M, Hammig $\mathrm{R}$, et al. beta-Arrestin2 influences the response to methadone in opioiddependent patients. Pharmacogenom J. 2011;11:258-66.

77. Chao MV, Rajagopal R, Lee FS. Neurotrophin signalling in health and disease. Clin Sci. 2006;110:167-73.

78. Grimm JW, Lu L, Hayashi T, Hope BT, Su TP, Shaham Y. Timedependent increases in brain-derived neurotrophic factor protein levels within the mesolimbic dopamine system after withdrawal from cocaine: implications for incubation of cocaine craving. J Neurosci. 2003;23:742-7.

79. Koskela M, Bäck S, Võikar V, Richie CT, Domanskyi A, Harvey BK, et al. Update of neurotrophic factors in neurobiology of addiction and future directions. Neurobiol Dis. 2017 97(Pt B):189-200.

80. de Cid R, Fonseca F, Gratacos M, Gutierrez F, Martin-Santos R, Estivill $\mathrm{X}$, et al. BDNF variability in opioid addicts and response to methadone treatment: preliminary findings. Genes Brain Behav. 2008;7:515-22.

81. Bie B, Zhang Z, Cai YQ, Zhu W, Zhang Y, Dai J, et al. Nerve growth factor-regulated emergence of functional delta-opioid receptors. J Neurosci. 2010;30:5617-28.

82. Levran O, Peles E, Hamon S, Randesi M, Zhao C, Zhang B, et al. Nerve growth factor beta polypeptide (NGFB) genetic variability: association with the methadone dose required for effective maintenance treatment. Pharmacogenomics. 2012;12:319-27.

83. Fonseca F, Gratacòs M, Escaramís G, De Cid R, Martín-Santos R, Farré $\mathrm{M}$, et al. ALDH5A1 variability in opioid dependent patients could influence response to methadone treatment. Eur Neuropsychopharmacol. 2014;24:420- 
84. Lötsch J, Prüss H, Veh RW, Doehring A. A KCNJ6 (Kir3.2, GIRK2) gene polymorphism modulates opioid effects on analgesia and addiction but not on pupil size. Pharmacogenet. Genomics. 2010;20:291-7.

85. Gerber JG, Rhodes RJ, Gal J. Stereoselective metabolism of methadone $N$-demethylation by cytochrome P4502B6 and 2C19. Chirality. 2004;16:3644.

86. Su Y, Zhan $\mathrm{Y}$, Wang $\mathrm{B}$, Wang SC, Dai $\mathrm{D}, \mathrm{Hu} \mathrm{G}$, et al. In vitro assessment of 24 CYP2D6 allelic isoforms on the metabolism of methadone. Drug Test Anal. 2017;9:216-20.

87. Lan T, Yuan L-J, Hu X-X, Zhou Q, Wang J, Huang X-X, et al. Effects of CYP2C19 variants on methadone metabolism in vitro. Drug Test Anal. 2017;9:634-9.

88. Foster DJ, Somogyi AA, Bochner F. Methadone $N$-demethylation in human liver microsomes: lack of stereoselectivity and involvement of CYP3A4. Br J Clin Pharmacol. 1999;47:403-12.

89. Kharasch ED. Current concepts in methadone metabolism and transport. Clin Pharmacol Drug Dev. 2017;6:125-34.

90. Shiran MR, Lennard MS, Iqbal MZ, Lagundoye O, Seivewright N, Tucker GT, et al. Contribution of the activities of CYP3A, CYP2D6, CYP1A2 and other potential covariates to the disposition of methadone in patients undergoing methadone maintenance treatment. Br J Clin Pharmacol. 2009;67:29-37.

91. Totah RA, Allen KE, Sheffels P, Whittington D, Kharasch ED.

Enantiomeric metabolic interactions and stereoselective human methadone metabolism. J Pharmacol Exp Ther. 2007;321:389-99.

92. Crettol S, Deglon JJ, Besson J, Croquette-Krokar M, Hammig R, Gothuey I, et al. ABCB1 and cytochrome P450 genotypes and phenotypes: influence on methadone plasma levels and response to treatment. Clin Pharmacol Ther. 2006;80:668-81. 
93. Fonseca F, de la Torre R, Diaz L, Pastor A, Cuyas E, Pizarro N, et al. Contribution of cytochrome $\mathrm{P} 450$ and $\mathrm{ABCB} 1$ genetic variability on methadone pharmacokinetics, dose requirements, and response. PLoS One. 2011;6:e19527.

94. Levran O, Peles E, Hamon S, Randesi M, Adelson M, Kreek MJ. CYP2B6 SNPs are associated with methadone dose required for effective treatment of opioid addiction. Addict Biol. 2013;18:709-16.

95. Totah RA, Sheffels P, Roberts T, Whittington D, Thummel K, Kharasch ED. Role of CYP2B6 in stereoselective human methadone metabolism. Anesthesiology. 2008;108:363-74.

96. Wang SC, Tsou HH, Ho IK, Lin KM, Liu YL. Pharmacogenomics study in a Taiwan methadone maintenance cohort. J Food Drug Anal. 2013;21:S62-8 (Internet).

97. Zanger UM, Klein K. Pharmacogenetics of cytochrome P450 2B6 (CYP2B6): advances on polymorphisms, mechanisms, and clinical relevance. Front Genet. 2013;4:24.

98. Wang SC, Ho IK, Tsou HH, Tian JN, Hsiao CF, Chen CH, et al. CYP2B6 polymorphisms influence the plasma concentration and clearance of the methadone S-enantiomer. J Clin Psychopharmacol. 2011;31:463-9.

99. Kharasch ED, Regina KJ, Blood J, Friedel C. Methadone pharmacogenetics: CYP2B6 polymorphisms determine plasma concentrations, clearance, and metabolism. Anesthesiology. 2015;123:114253.

100. Dobrinas M, Crettol S, Oneda B, Lahyani R, Rotger M, Choong E, et al. Contribution of CYP2B6 alleles in explaining extreme (S)-methadone plasma levels: a CYP2B6 gene resequencing study. Pharmacogenet Genom. 2013;23:84-93.

101. Tsai HJ, Wang SC, Tian JN, Chang TK, Ho IK, Hsiao CF, et al. PXR polymorphisms interacted with CYP2B6 polymorphisms on methadone metabolites. J Clin Psychopharmacol. 2013;33:137-40. 
102. Lee HY, Li JH, Sheu YL, Tang HP, Chang WC, Tang TC, et al. Moving toward personalized medicine in the methadone maintenance treatment program: a pilot study on the evaluation of treatment responses in Taiwan. Biomed Res Int. 2013;2013:741403.

103. Dennis BB, Bawor M, Thabane L, Sohani Z, Samaan Z. Impact of ABCB1 and CYP2B6 genetic polymorphisms on methadone metabolism, dose and treatment response in patients with opioid addiction: a systematic review and meta-analysis. PLoS One. 2014;9: e86114.

104. Wang JS, DeVane CL. Involvement of CYP3A4, CYP2C8, and CYP2D6 in the metabolism of (R)- and (S)-methadone in vitro. Drug Metab Dispos. 2003;31:742-7.

105. Gelston EA, Coller JK, Lopatko OV, James HM, Schmidt H, White JM, et al. Methadone inhibits CYP2D6 and UGT2B7/2B4 in vivo: a study using codeine in methadone- and buprenorphine-maintained subjects. Br J Clin Pharmacol. 2012;73:786-94.

106. Teh LK, Bertilsson L. Pharmacogenomics of CYP2D6: molecular genetics, interethnic differences and clinical importance. Drug Metab Pharmacokinet. 2012;27:55-67.

107. Eap CB, Broly F, Mino A, Hammig R, Deglon JJ, Uehlinger C, et al. Cytochrome P450 2D6 genotype and methadone steady-state concentrations. J Clin Psychopharmacol. 2001;21:229-34.

108. Coller JK, Joergensen C, Foster DJ, James H, Gillis D, Christrup L, et al. Lack of influence of CYP2D6 genotype on the clearance of (R)-, (S)- and racemic-methadone. Int J Clin Pharmacol Ther. 2007;45:410-7.

109. Wang S-C, Ho I-K, Tsou H-H, Liu S-W, Hsiao C-F, Chen C-H, et al. Functional genetic polymorphisms in CYP2C19 gene in relation to cardiac side effects and treatment dose in a methadone maintenance cohort. OMICS. 2013;17:519-26.

110. Crettol S, Digon P, Golay KP, Brawand M, Eap CB. In vitro Pglycoprotein-mediated transport of (R)-, (S)-, (R, S)-methadone, LAAM and 
their main metabolites. Pharmacology. 2007;80:304-11.

111. Zhou S-F. Structure, function and regulation of P-glycoprotein and its clinical relevance in drug disposition. Xenobiotica. 2008;38:802-32.

112. Callaghan R, Riordan JR. Synthetic and natural opiates interact with Pglycoprotein in multidrug- resistant cells. J Biol Chem. 1993;268:16059-64.

113. Hung CC, Chiou MH, Teng YN, Hsieh YW, Huang CL, Lane HY. Functional impact of ABCB1 variants on interactions between Pglycoprotein and methadone. PLoS One. 2013;8: e59419.

114. Hoffmeyer S, Burk O, von Richter O, Arnold HP, Brockmoller J, Johne A, et al. Functional polymorphisms of the human multidrug-resistance gene: multiple sequence variations and correlation of one allele with Pglycoprotein expression and activity in vivo. Proc Natl Acad Sci USA. 2000;97:3473-8.

115. Coller JK, Barratt DT, Dahlen K, Loennechen MH, Somogyi AA. $\mathrm{ABCB} 1$ genetic variability and methadone dosage requirements in opioiddependent individuals. Clin Pharmacol Ther. 2006;80:682-90.

116. Levran O, O'Hara K, Peles E, Li D, Barral S, Ray B, et al. ABCB1 (MDR1) genetic variants are associated with methadone doses required for effective treatment of heroin dependence. Hum Mol Genet. 2008;17:221927.

117. Zahari Z, Lee CS, Ibrahim MA, Musa N, Mohd Yasin MA, Lee YY, et al. Relationship between $\mathrm{ABCB} 1$ polymorphisms and serum methadone concentration in patients undergoing methadone maintenance therapy (MMT). Am J Drug Alcohol Abuse. 2016;42:587-96.

118. Bart G, Lenz S, Straka RJ, Brundage RC. Ethnic and genetic factors in methadone pharmacokinetics: a population pharmacokinetic study. Drug Alcohol Depend. 2014;145:185-93.

119. Crettol S, Deglon JJ, Besson J, Croquette-Krokar M, Hammig R, Gothuey I, et al. No influence of ABCB1 haplotypes on methadone dosage 
requirement. Clin Pharmacol Ther. 2008;83:668-70.

120. Yang HC, Chu SK, Huang CL, Kuo HW, Wang SC, Liu SW, et al. Genome-wide pharmacogenomic study on methadone maintenance treatment identifies SNP rs17180299 and multiple haplotypes on CYP2B6, SPON1, and GSG1L associated with plasma concentrations of methadone $\mathrm{R}$ - and S-enantiomers in heroin-dependent patients. PLoS Genet. 2016;12:e1005910.

121. van Leeuwen EM, Kanterakis A, Deelen P, Kattenberg MV, Slagboom PE, de Bakker PIW, et al. Population-specific genotype imputations using minimac or IMPUTE2. Nat Protoc. 2015;10:1285-96.

122. Torrens M, Fonseca F, Galindo L, Farré M. Opioid addiction: shortand long-acting opioids. In: el-Guebaly N, Carrà G, Galanter M, editors. Textb. Addiciont Treat. Int. Prespectives. Milan: Springer; 2015. p. 367-80.

123. Wachman EM, Hayes MJ, Sherva R, Brown MS, Davis JM, Farrer LA, et al. Variations in opioid receptor genes in neonatal abstinence syndrome. Drug Alcohol Depend. 2015;155:253-9.

124. Zahari Z, Lee CS, Ibrahim MA, Musa N, Mohd Yasin MA, Lee YY, et al. The AC/AG diplotype for the $118 \mathrm{~A}>\mathrm{G}$ and $\mathrm{IVS} 2+691 \mathrm{G}>\mathrm{C}$ polymorphisms of OPRM1 gene is associated with sleep quality among opioid-dependent patients on methadone maintenance therapy. Pain Ther. 2016;5:43-54.

125. Wang S-C, Tsou H-H, Chung R-H, Chang Y-S, Fang C-P, Chen C-H, et al. The association of genetic polymorphisms in the $\kappa$-opioid receptor 1 gene with body weight, alcohol use, and withdrawal symptoms in patients with methadone maintenance. J Clin Psychopharmacol. 2014;34:205-11.

126. Chen CH, Wang SC, Tsou HH, Ho IK, Tian JN, Yu CJ, et al. Genetic polymorphisms in CYP3A4 are associated with withdrawal symptoms and adverse reactions in methadone maintenance patients. Pharmacogenomics. 2011;12:1397-406.

127. Tian J-N, Ho I-K, Tsou H-H, Fang C-P, Hsiao C-F, Chen C-H, et al. 
$U G T 2 B 7$ genetic polymorphisms are associated with the withdrawal symptoms in methadone maintenance patients. Pharmacogenomics. 2012;13:879-88.

128. Zahari Z, Lee CS, Ibrahim MA, Musa N, Mohd Yasin MA, Lee YY, et al. Relationship between CYP2B6*6 and cold pressor pain sensitivity in opioid dependent patients on methadone maintenance therapy (MMT). Drug Alcohol Depend. 2016;165:143-50.

129. Morrish GA, Foster DJR, Somogyi AA. Differential in vitro inhibition of $\mathrm{M} 3 \mathrm{G}$ and $\mathrm{M} 6 \mathrm{G}$ formation from morphine by (R)- and (S)-methadone and structurally related opioids. Br J Clin Pharmacol. 2006;61:326-35.

130. Wong SH, Wagner MA, Jentzen JM, Schur C, Bjerke J, Gock SB, et al. Pharmacogenomics as an aspect of molecular autopsy for forensic pathology/toxicology: does genotyping CYP 2D6 serve as an adjunct for certifying methadone toxicity? J Forensic Sci. 2003;48:1406-15.

131. Bunten H, Liang WJ, Pounder D, Seneviratne C, Osselton MD. CYP2B6 and OPRM1 gene variations predict methadone-related deaths. Addict Biol. 2011;16:142-4.

132. Bunten H, Liang WJ, Pounder DJ, Seneviratne C, Osselton D. OPRM1 and CYP2B6 gene variants as risk factors in methadone-related deaths. Clin Pharmacol Ther. 2010;88:383-9.

133. Richards-Waugh LL, Primerano DA, Dementieva Y, Kraner JC, Rankin GO. Fatal methadone toxicity: potential role of CYP3A4 genetic polymorphism. J Anal Toxicol. 2014;38:541-7.

134. Ahmad T, Sabet S, Primerano DA, Richards-Waugh LL, Rankin GO. Tell-tale SNPs: the role of CYP2B6 in methadone fatalities. J Anal Toxicol. 2017;41:325-33.

135. Icick R, Peoc'h K, Ksouda K, Bloch V, Laplanche JL, Lépine JP, et al. OPRM1 polymorphism and lifetime suicide attempts among stabilized, methadone-maintained outpatients. Psychiatry Res. 2014;218:259-60.

136. Krantz MJ, Lewkowiez L, Hays H, Woodroffe MA, Robertson AD, 
Mehler PS. Torsade de pointes associated with very-high-dose methadone. Ann Intern Med. 2002;137:501-4.

137. Chou R, Cruciani RA, Fiellin DA, Compton P, Farrar JT, Haigney MC, et al. Methadone safety: a clinical practice guideline from the american pain society and college on problems of drug dependence, in collaboration with the heart rhythm society. J Pain. 2014;15:321-37.

138. Mujtaba S, Romero J, Taub CC. Methadone, QTc prolongation and torsades de pointes: current concepts, management and a hidden twist in the tale? J Cardiovasc Dis Res. 2013;4:229-35.

139. Martell BA, Arnsten JH, Ray B, Gourevitch MN. The impact of methadone induction on cardiac conduction in opiate users. Ann Intern Med United States. 2003;139:154-5.

140. Butler B, Rubin G, Lawrance A, Batey R, Bell J. Estimating the risk of fatal arrhythmia in patients in methadone maintenance treatment for heroin addiction. Drug Alcohol Rev. 2011;30:173-80.

141. Fonseca F, Marti-Almor J, Pastor A, Cladellas M, Farré M, de la Torre $\mathrm{R}$, et al. Prevalence of long QTc interval in methadone maintenance patients. Drug Alcohol Depend. 2009;99:327-32.

142. Csajka C, Crettol S, Guidi M, Eap CB. Population genetic-based pharmacokinetic modeling of methadone and its relationship with the QTc interval in opioid-dependent patients. Clin Pharmacokinet. 2016;55:1521-33.

143. Hajj A, Ksouda K, Peoc'h K, Curis E, Messali A, v LL, et al. KCNH2 polymorphism and methadone dosage interact to enhance QT duration. Drug Alcohol Depend. 2014;141:34-8.

144. Eap CB, Crettol S, Rougier JS, Schlapfer J, Sintra Grilo L, Deglon JJ, et al. Stereoselective block of hERG channel by (S)-methadone and QT interval prolongation in CYP2B6 slow metabolizers. Clin Pharmacol Ther. 2007;81:719-28.

145. Ansermot N, Albayrak O, Schlapfer J, Crettol S, Croquette-Krokar M, Bourquin M, et al. Substitution of (R, S)-methadone by (R)-methadone: 
impact on QTc interval. Arch Intern Med. 2010;170:529-36.

146. Carlquist JF, Moody DE, Knight S, Johnson EG, Fang WB, Huntinghouse JA, et al. A possible mechanistic link between the CYP2C19 genotype, the methadone metabolite ethylidene-1,5-dimethyl-3,3diphenylpyrrolidene (EDDP), and methadone-induced corrected QT interval prolongation in a pilot study. Mol Diagn Ther. 2015;19:131-8.

147. Eap CB, Cuendet C, Baumann P. Binding of d-methadone, 1methadone, and dl-methadone to proteins in plasma of healthy volunteers: role of the variants of alpha 1-acid glycoprotein. Clin Pharmacol Ther. 1990;47:338-46.

148. Crowley NA, Kash TL. Kappa opioid receptor signaling in the brain: circuitry and implications for treatment. Prog Neuro Psychopharmacol Biol Psychiatry. 2015;62:51-60. 